\title{
Marriage and Women's Citizenship in the United States, 1830-1934
}

\section{Citation}

Cott, Nancy F. 1998. Marriage and women's citizenship in the United States, 1830-1934.

American Historical Review 103, no. 5: 1440-1474.

\section{Published Version}

http://dx.doi.org/10.2307/2649963

\section{Permanent link}

http://nrs.harvard.edu/urn-3:HUL.InstRepos:3207343

\section{Terms of Use}

This article was downloaded from Harvard University's DASH repository, and is made available under the terms and conditions applicable to Other Posted Material, as set forth at http:// nrs.harvard.edu/urn-3:HUL.InstRepos:dash.current.terms-of-use\#LAA

\section{Share Your Story}

The Harvard community has made this article openly available.

Please share how this access benefits you. Submit a story.

Accessibility 


\title{
Marriage and Women's Citizenship in the United States, 1830-1934
}

\author{
NANCY F. COTT
}

IN THE United States, where the creation of new citizens is an essential (if contested) tradition, there must certainly be more than one understanding of what citizenship is. A focus on immigration and naturalization emphasizes that citizenship is a political fiction, an identification that can be put on like new clothing by the properly readied wearer. Or taken off. Being a fiction does not mean that citizenship is false but that it is purposefully constructed, all the more reason that its meanings and the rewards and obligations it conveys may vary over time and among citizens. Citizenship represents not only the bond between an individual and a state but also a bond between one individual and many others. It represents an attachment to a political community, different from membership in a kinship group because the bonds are only figurative. The symbolic dimension is no less important than the material privileges and obligations that ensue from citizenship. Citizenship is a "powerful instrument of social closure," in Rogers Brubaker's words. The boundedness of the citizenry marks the nation-state's power.'

Whatever else it entails, citizenship is a distinctive form of social classification that colors personal standing in any community. It confers an identity that may have deep personal and psychological dimensions at the same time that it expresses belonging. The same can be said for marriage. Marriage also is a civil status that can

I am grateful to the National Endowment for the Humanities, the Harvard Law School Liberal Arts Fellowship, and the Schlesinger Library on the History of Women in America, Radcliffe College, for support for this project. Numerous scholars commented generously and usefully on several earlier versions of this essay, and I would like to express my thanks to them: T. Alexander Aleinikoff, Ellen DuBois, Eric Foner, Lori D. Ginzberg, Linda Gordon, Alexander Keyssar, Martha Minow, David Montgomery, Peggy Pascoe, Reva Siegel, Rogers Smith, Lea VanderVelde, the anonymous readers for the $A H R$, and the audiences at the UCLA History Department, the Harvard Law School, and the Yale Law School in 1994, and the New York University Law School in 1997. I am indebted to Jessica Steigerwald for excellent research assistance.

1 Rogers Brubaker, Citizenship and Nationhood in France and Germany (Cambridge, Mass., 1992), $\mathrm{x}$. On definitions of citizenship, see Frederick Van Dyne, Citizenship of the United States (Rochester, N.Y., 1904), iv; Catheryn Seckler-Hudson, Statelessness: With Special Reference to the United States (Washington, D.C., 1934), 8-10; T. H. Marshall and Tom Bottomore, Citizenship and Social Class (London, 1992), 24; James H. Kettner, The Development of American Citizenship, 1608-1870 (Chapel Hill, N.C., 1978), esp. 41-43; Rogers M. Smith, Civic Ideals: Conflicting Visions of Citizenship in U.S. History (New Haven, Conn., 1997). Linda K. Kerber, "The Meanings of Citizenship," Journal of American History 84 (December 1997): 836-37, stresses the variations in understanding and holding of citizenship; and see Etienne Balibar, "The Nation Form: History and Ideology," Review, Fernand Braudel Center 13, no. 3 (1990): 346-56; and Benedict Anderson, Imagined Communities, rev. edn. (New York, 1991), 5-7, on the concept of the nation as an imagined (limited and sovereign) political community. 
be taken on or ended, yet when in force has a powerful impact on personal identity. If we ordinarily think of marriage as an arrangement chosen for the living of private life, it has to be recognized as a public institution, a part of the public order, too: it is constituted by the state; its form and requirements are created by public authority and it operates as systematic public sanction, bringing rights and privileges along with duties. Obligations and benefits of marriage inhere in many legal and governmental provisions, from property holding to citizenship, immigration, military, and tax policy. All this goes without saying until some of those excluded bring it up, as same-sex couples have recently. In the history of the United States, the inability of slaves to marry legally also demonstrates keenly that access to marriage is a civil right. ${ }^{2}$

Marriage and citizenship are not unrelated in U.S. history. Immigration and naturalization policies in the United States have historically paid attention to the family status of immigrants. Since the mid-twentieth century, "family reunification" has been the "cornerstone" of U.S. immigration policy, in one scholar's words. The admission priority given to members of American citizens' nuclear families distinguishes the United States from most other immigrant-admitting nations, which look first to economic or occupational considerations. ${ }^{3}$ As the queues of would-be citizens taking matrimonial vows before justices of the peace just prior to April 1, 1997, confirmed, there is a general impression that marrying an American brings an advantage for gaining citizenship. Few know or recall that marrying a foreigner once deprived Americans of their citizenship, however. This was true for a considerable stretch of U.S. history, for women only, never for American men. American men could, on the other hand, turn sweethearts from other nations into American citizens by marrying them, during the years between 1855 and 1922 , a privilege American women never had. ${ }^{4}$

Does this historical difference in the relation between marriage and citizenship for women and men mean that there is something peculiar-more tenuous or vulnerable-about women's (or perhaps married women's) citizenship in the United States? To answer "yes" would suggest that citizenship can be delivered in different degrees of permanence or strength. It would suggest that citizenship is not

2 Michael Grossberg deftly surveys and analyzes the statute and case law on access to marriage in Governing the Hearth: Law and the Family in Nineteenth-Century America (Chapel Hill, N.C., 1985), 31-152. For materials on both sides of the recent controversy, see Same-Sex Marrtage: Pro and Con, Andrew Sullivan, ed. (New York, 1997). The promotion of private rites for slive unions, always breakable by masters' whims, not upheld by the state, quintessentially marked slaves as lacking in the basic civil status of persons. See Margaret Burnham, "An Impossible Marriage: Slave Law and Family Law," Law and Inequality 5 (1987): 187-225.

3 Vernon M. Briggs, Jr., Immigration Policy and the American Labor Force (Baltimore, Md., 1984), $68-69$; this point is a commonplace in the literature.

4 See Clyde Haberman, "In Citizenship, in Sickness and in Health," New York 7imes (February 21, 1997): 8 . The nearest likeness to American women being deprived of citizenship because of marriage to aliens is those men who married native American women in the nineteenth century and resided in Indian territory, wishing to leave their American citizenship behind while under Indian sovereignty. U.S. authorities were never happy to regard these men as having divested themselves of U.S. citizenship via marriage, however. See James Brown Scott, David J. Hill, and Gaillard Hunt. Citizenship of the United States, Expatriation, and Protection Abroad [59th Cong., 2d sess., H.R. Doc. 326] (Washington, D.C., 1906), 59-62; U.S. v. Rogers 45 U.S. (4 How.), 567 (1846); Lx parte Kenyon, 5 Dill. 385114 Fed. Cas. 353, C.C. W.D. Arkansas] (1878); Ex parte Reynolds, 5 Dill. 394 [20 Fed. Cis. 582, C.C. W.D. Arkansas] (1879); "Report of the Secretary of the Interior," 49th Cong. 1st sess (1885-86), House Executive Documents, vol. 11:28-30; Roff : Bumey, 168 U.S. 218 (1897). 
a definitive either/or proposition-you are or you are not-but a compromisable one, and if so for women, perhaps for some men. To explore this question-to initiate a history of U.S. citizenship that starts with the female citizen-requires centering on the institution of marriage. ${ }^{5}$ It requires recognizing marriage as an institution that helps to found both men's and women's identity in the polity, an institution in which the nation-state has historically had a great interest. Enabling legal marriage to exist and patrolling its borders, governments are involved in creating civil statuses for both men and women. In every nation, laws and public policies have mandated authority relations and dependency relations in marriage and directed these to be reproduced through the socialization of future citizens. The institution of marriage has thus been the vehicle for the state's part in forming and sustaining the gender order-or, it might be said, in forming and sustaining gender itself (that is, the complex set of social relations defining male and female, masculinity and femininity). The connection between marriage and citizenship, embedded in political traditions and practices, emerges to the light only in peculiar specific locations such as the treatment of women citizens who marry aliens (although its impact is much more profound and broadly diffused). Looking at congressional actions taken in $1855,1907,1922$, and 1934 concerning the relation between marriage and citizenship is one way to begin to see it. 6

While direct regulation of marriage such as the stipulation of ceremonies and obligations and the authorization of divorce takes place at the state level in the United States, the national government's hand in mandating marriage can be seen historically in areas of federal control such as immigration. ${ }^{7}$ Any modern nationstate is likely to concern itself with marriage, most basically because of concern for reproduction of its population. Reproduction creates the qualities and characteristics of the body politic. By defining sexual reproduction that is deemed legitimate,

\footnotetext{
5 Although there has been considerable treatment of the "gendered" nature of citizenship by feminist political scientists and historians, little of it has focused on the institution of marriage as such. See, however, Linda K. Kerber, "The Paradox of Women's Citizenship in the Early Republic: The Case of Martin vs. Massachusetts, 1805," AHR 97 (April 1992): 349-78; Alice Kessler-Harris, "Designing Women and Old Fools: The Construction of the Social Security Amendments of 1939," in Linda K. Kerber, et al., eds., U.S. Histony as Women's Histony: New Feminist Essays (Chapel Hill, N.C., 1995), 87-106; Nancy Fraser and Linda Gordon, "Civil Citizenship against Social Citizenship? On the Ideology of Contract-versus-Charity," in Bart van Steenbergen, ed., The Condition of Citizenship (Thousand Oaks, Calif., 1994), 90-107; Laura F. Edwards, "The Marriage Covenant Is at the Foundation of All Our Rights': The Politics of Slave Marriages in North Carolina after Emancipation," Law and History Review 14 (Spring 1996): 81-124; Megan J. McClintock, "Civil War Pensions and the Reconstruction of Union Families," Journal of American History 83 (September 1996): 456-80; Susan Pedersen, "Gender, Welfare, and Citizenship in Britain during the Great War," $A H R 95$ (October 1990): 983-1006.

"I was first interested in this topic by Virginia Sapiro, "Women, Citizenship and Nationality: Immigration and Naturalization Policies in the United States," Politics and Society 13, no. 1 (1984): 1-26. Waldo Emerson Waltz, The Nationality of Married Women: A Study of Domestic Policies and International Legislation, Illinois Studies in the Social Sciences, vol. 22, no. 1 (Urbana, I1l., 1937), was the first comprehensive history and is still extremely valuable; however, Candice Dawn Bredbenner, "Toward Independent Citizenship: Married Women's Nationality Rights in the United States, 1855-1937" (PhD dissertation, University of Virginia, 1990), added significant dimension to the narrative by emphasizing the impact of immigration restriction on married women's citizenship; and see the recently published revision, Candice Lewis Bredbenner, A Nationality of Her Own: Women, Marriage, and the Law of Citizenship (Berkeley, Calif., 1998).

7 See Jill Elaine Hasday, "Federalism and the Family Reconstructed," UCLA Law Review 45 (June 1998), presenting painstaking historical research to refute the notion of exclusive localism in family law.
} 
marriage joins naturalization and immigration policies in guarding the characteristics of the body politic, shaping (however imperfectly) "the people." Marriage is all the more important in this regard in a nation of immigrants such as the United States, where differing cultural groups are likely to amalgamate, and birth in the dominion warrants national citizenship. By creating incentives for some kinds of marriages and disincentives for others, by preventing or punishing some marriages and not others, the states and the nation have sculpted the body politic. A long history of regulations nullifying or criminalizing marriage between whites and people of color in the United States, for example, has signally shaped the racial order (and, arguably "race" itself)."

In proposing that the state becomes instrumental in forming gender or race via marriage policy, I am following the lead of critical legal theorists in accepting the social importance of "the law" (including the U.S. Constitution, state and federal legislation, courts' adjudication, and enforcement powers). Critical legal theory speaks to historians in emphasizing the "fundamentally constitutive character of legal relations in social life," in Robert Gordon's words-the extent to which law, as an authorizing discourse, establishes what can be understood as "common sense" or "the facts of life" without itself being insulated from the impress of cultural and expert discourses of other sorts." Nowhere is law likely to "authorize" more effectively than where it echoes and reinforces predominant religious dictates, as is true in the United States with respect to marriage. This approach does not necessarily mean that "the law" is coherent and one thing only, without (possibly) plural sources of energy or origin, without internal conflict. Indeed, if one wanted to argue that "the law" in the United States is typically internally conflicted and plural in origin-yet succeeds in supplying an authoritative composite face-both marriage and citizenship would provide exemplary sites for investigation. ${ }^{10}$

My investigation here is limited to formal structures-the grants or impositions of attributes envisioned by male legislators, expressed legally, and enforced practically as citizenship or marital status. The self-assessments of women or men inhabiting the statuses of citizens or spouses will certainly fail to match those structures exactly. Law and policy shape and interact with personal assessments and actions without fully determining them. The broad range of behavior and selfconsciousness acknowledged to exist within the categories of "husband" and "wife" may be instructive in imagining a possible range of self-understandings among citizens, too. Full citizens may feel insufficiently attached or animated to take advantage of their powers (as in low voter turnout today). On the other hand,

"Compare Michael Omi and Howard Winant's concept of "racial formation" in Racial Formation in the United States: From the 1960s to the 1980s (New York, 1986). Forty-one states at some time in their histories criminalized or nullified marriages between whites and Negroes, mulattoes, Asians of various denotation, and/or Indians. The laws are summarized in David H. Fowler. Northern Attitudes towards Interracial Marriage: Legislation and Public Opinion in the Middle Atlantic and the States of the Old Northwest, 1780-1930 (New York, 1987), appendix.

"Robert Gordon, "Critical Legal Histories," Stanford Law Review 57 (1984): 104; and see Christopher Tomlins, "Subordination, Authority, Law: Subjects in Labor History," International Labor and Working-Class History 47 (Spring 1995), esp. 63-64, 67-68.

1" On the possibly plural sources of legal authority, see Hendrik Hartog's engaging "Pigs and Positivism," Wisconsin Law Review 4 (July 1985), esp. 932-34. Without denying the extent to which Christian religious dictates structured marriage, I am focusing here on the secular public order. 
individuals not fully clothed with the power of citizens may nonetheless assert themselves in governance, acting vigorously in unofficial modes, as Elsa Barkley Brown has emphasized in her study of the political behavior of ex-slaves in post-Emancipation Richmond, Virginia, for example. Whether or not politicians or voting men thought unenfranchised women were full citizens, hundreds of thousands of members of female voluntary associations seem to have felt very much attached to and invested in the commonweal. ${ }^{11}$ Admittedly, a study of law and policy cannot capture such personal dimensions of citizenship, but it can establish the structures of expectations, encouragements, and coercions in which individuals act.

Before the Crvil War, states had the larger part in defining citizens. National citizenship was inchoate. No document stipulated exactly what it meant to be a citizen of the United States. The new republic presented itself as offering civic incorporation to all those willing to consent to allegiance and adhere to democratic political principles. ${ }^{12}$ Yet presuppositions about racial assimilability interfered. In the Constitution, the population to be counted for congressional representation included free women and children but excluded "Indians not taxed" and assessed slaves at three-fifths of their number, reading the latter two groups out of "the people." When the first federal legislation on naturalization passed in 1790 , it allowed only "free white persons" to become naturalized citizens. The racial qualifier was accepted without occasioning floor debate. ${ }^{13}$ If to be naturalized is to be embraced by the state in a legal fiction of rebirth (as the etymology of the word

${ }^{11}$ Elsa Barkley Brown, "Negotiating and Transforming the Public Sphere: African American Political Life in the Transition from Slavery to Freedom," Public Culture 7 (1994): 119-26. On women's political activity outside the electoral arena, see, for example, Paula Baker, "The Domestication of Politics: Women and American Political Society, 1780-1920," AHR 89 (June 1984): 620-47; Sara M. Evans, Born for Liberty: A History of Women in America (New York, 1989), 119-44; Suzanne Lebsock, "Women and American Politics, 1880-1920," in Louise A. Tilly and Patricia Gurin, eds., Women, Politics and Change (New York, 1990), 35-62; Manuela Thurner, "'Better Citizens without the Ballot': American Antisuffrage Women and Their Rationale during the Progressive Era," Journal of Women's History 5 (Spring 1993): 33-60. On female citizenship viewed through constitutional law, see Rogers M. Smith, "One United People': Second-Class Female Citizenship and the American Quest for Community," Yale Journal of Law and the Humanities 1 (May 1989); for a summary of the outlook of state constitutional convention delegates on women's citizenship, see Rowland Berthoff, "Conventional Mentality: Free Blacks, Women, and Business Corporations as Unequal Persons, 1820-1870,"Journal of American History 76 (December 1989): 753-84.

12 See Kettner, Development, 213-18, 237-39; and Smith, Civic Ideals, 119-20, 160-61, on states and citizenship. Before federal immigration restriction began in 1875 , the United States did not maintain fully "open borders" because the individual states, exercising their police powers, could and did exclude in-migrants for causes such as criminal record, disease, poverty, slavery, and racial difference, as Gerald L. Neuman emphasizes in Strangers to the Constitution: Immigrants, Borders, and Fundamental Law (Princeton, N.J., 1996), esp. 19-51.

13 Jan Lewis, "Of Every Age Sex \& Condition': The Representation of Women in the Constitution," Journal of the Early Republic 15 (Fall 1995): 359-88. Two of the three senators delegated to draft the first naturalization law were from slaveholding states, Virginia and South Carolina, whose state constitutions limited naturalization to free white persons. The phrase "free white persons" appeared in the committee's draft and caused no comment recorded in the Annals of Congress, while the proper length of residency caused heated dialogue. Annals of Congress, 1st Cong., $2 \mathrm{~d}$ sess. (1790), 1057, 1109-25. Compare George M. Fredrickson, White Supremacy: A Comparative Study in American and South African History (New York, 1981), 145, who argues that the 1790 naturalization law indicated Americans" "sense of themselves as a homogeneous community ... White Americans ... reserved the 
suggests)-to mimic the citizen who "naturally" belongs to the national community-then this was especially telling. Politics and legal practice answered the question of whether free blacks born in the United States were citizens inconsistently (and more often negatively than positively) before the Fourteenth Amendment. In 1857, Justice Roger Brooke Taney's opinion for the Supreme Court said descendants of African slaves, not having come from "the people" who formed the United States, were excluded from birthright citizenship. Yet Dred Scott vs. Sandford was not a unanimous decision. "There are two lines of authority directly in conflict, with a third line midway in between," concluded a State Department research effort of 1906, reviewing the history of citizenship of "free negroes" before and after Dred Scott. ${ }^{14}$

Nor was it clear before the Civil War what rights citizenship conveyed, or whether they applied equally to all. When Attorney-General Edward Bates pored over law books and court records to review this subject in 1862, he found the effort "fruitless," reporting that it was "now as little understood in its details and elements, and the question as open to argument and speculative criticism as it was at the beginning of the Government. Eighty years of practical enjoyment of citizenship, under the Constitution, have not sufficed to teach us either the exact meaning of the word, or the constituent elements of the thing we prize so highly." The Constitution left voting a privilege that the separate states could grant or deny on the basis of qualifications that they might establish. Not until the Fourteenth and Fifteenth Amendments did states have constitutional guidelines to follow. As many as twenty-two of the states and territories during the nineteenth century enfranchised white male aliens who had declared their intentions to become citizens. In the Dred Scott decision, therefore, Justice Taney could dismiss facts of blacks voting in some Northern states as conclusive evidence of their citizenship. And if white women were citizens, then citizenship could not be defined to include office-holding and jury and military service, either. ${ }^{15}$

If it did not convey suffrage or political rights, did citizenship have usefulness or

option to apply tests of cultural and racial compatibility to those who sought admission to their own ranks."

${ }^{14}$ Dred Scotl v. Sandford, 60 U.S. (19 How.), 393; J. Scott, et al., Citizenship of the United States, Expatriation, and Protection, 62-67 (quotation on 62)-these pages provide quite a useful summary, including court decisions; John Pearson Roche, The Early Development of United States Citizenship (Ithaca, N.Y., 1949), 19-25; Smith, Civic Ideals, 187-88: "courts throughout the country were reluctant to declare free blacks wholly nonmembers of the polity or to recognize them as full citizens"; Kettner, Development, 41-42, on naturalization as a legal fiction of rebirth. It took the Fourteenth Amendment to declare definitively that anyone born in the mation's jurisdiction was a citizen. Common-law tradition inherited from Britain supported that understanding, but since it was a feudally rooted and deterministic practice, it had not seemed entirely appropriate to a polity based on consent as the United States claimed to be. See Smith, Civic Ideals, 154-59; and Kettner, Development.

is Bates quoted in Patricia Lucie. "On Being a Free Person and a Citizen by Constitutional Amendment," Journal of American Studies 12 (1978): 355; Dred Scott v. Sandford, 60 U.S. (19 How.), 422; on aliens voting, see Leon E. Aylsworth, "The Passing of Alien Suffrage," American Political Science Review 25 (February 1931): 114-16: Bredbenner, "Toward Independent Citizenship," 84; J. B. Raskin, "Legal Aliens, Local Citizens: The Historical, Constitutional, and Theoretical Meanings of Alien Suffrage." University of Pennsylvania Law Review 141 (April 1993): 1391-1470; Neuman, Strangers to the Constitution, 63-71. Linda K. Kerber sheds new light on citizenship as compused of obligations as well as rights in No Constitutional Right to Be Ladies: Women and the Obligations of Citizenship (New York, 1998). 
participatory meaning? Did the belonging indicated by citizenship have some value beyond being a resident only? ${ }^{16}$ Citizens who petitioned the U.S. government had to be heard, whereas noncitizens could be ignored. Civil rights such as the right to make contracts, sue and testify in court, own and devise property, and pursue an occupation, all very important in daily life and prosperity, were most commonly assumed to inhere in citizenship. The common law barred aliens from owning, inheriting, or devising real property-significant economic (and political) restraints-and the states initially followed suit. As the nineteenth century progressed, states (and international treaties) moved unevenly but unmistakably to remove these handicaps. Women, on the other hand, while presumably citizens, lost their property rights upon marriage under the doctrine of coverture. Like voting, then, rights to own and manipulate property were less than equivalent with citizenship. As the dissenter Justice Benjamin R. Curtis wrote in his Dred Scott opinion, "the truth is, that citizenship, under the Constitution of the United States, is not dependent on the possession of any particular political or even of all civil rights; and any attempt so to define it must lead to error."17

Only the minimal definition of national citizenship, meaning the individual's allegiance and the nation's reciprocal guarantee of protection, commanded unqualified assent during the nineteenth century. A unanimous Supreme Court announced this in 1875, in Minor vs. Happersett. The court could justify no more expansive or detailed definition. Wrestling with the fact that the Constitution fails to define citizenship and at points uses the word "person" or "inhabitant" instead of "citizen," the justices could not imagine that the framers envisioned less than a political community, since "There cannot be a nation without a people." They offered a minimalist definition: citizenship was "membership of a nation, and nothing more." 18 This purposely ignored the more generous and activist concept that had driven American colonists to separate themselves from England and animated revolutionary-era political rhetoric about devotion to the public good.

${ }^{16}$ It is easy to agree with Rogers Smith's contention that "the interests of all people in belonging to viable and valued political communities are enormous ... few if any people can hope to pursue their needs and aspirations successfully in the absence of such bounded political communities." Smith, Civic Ideals, 474. Compare Frederick Douglass's eloquently terse characterization of the condition of Northern free blacks in 1853: "Aliens we are in our native land"; quoted in David Blight, Frederick Douglass' Civil War (Baton Rouge, La., 1989), 13; and feminist Rheta Childe Dorr's complaint fifty years later in What Eight Million Women Want (Boston, 1910), 290: "although every one knows that women own property, pay taxes, successfully manage their own business affairs, and do an astonishing amount of community work as well, no one ever thinks of them as citizens."

${ }^{17}$ One did not have to be a citizen to benefit from the protections of the Bill of Rights, which extended to "persons." Noncitizens could claim rights to habeas corpus or a jury trial, for instance. I am grateful to Akhil Amar for pointing out that the Senate in the 1860s refused to hear petitions from aliens, because the Constitution speaks of the right of "the people" to petition, but it did hear women's petitions; see Amar, "The Bill of Rights and the Fourteenth Amendment," Yale Law Journal 101 (1992): 1282-83. See also Nina Morais, "Sex Discrimination and the Fourteenth Amendment: Lost History," Yale Law Journal 97 (1988): 1153-72. On common-law prohibition of alien property owning, devising, and inheriting, see Max J. Kohler, "Legal Disabilities of Aliens in the United States," American Bar Association Journal 16 (February 1930): 113-17; Kettner, Development; Richard R. Powell, Powell on Real Property, rev. edn. by Patrick J. Rohan, vol. 1 (New York, 1993), 100-09. Dred Scott v. Sandford, 60 U.S. (19 How.), 393, 583.

${ }^{18}$ Minor v. Happersett, 88 U.S. (21 Wall.), 162, at 165, 166. Ellen Carol DuBois, "Outgrowing the Compact of the Fathers: Equal Rights, Woman Suffrage, and the United States Constitution, 1820-1878," Journal of American History 74 (December 1987): 836-62, alerted me to the importance of Minor v. Happersett; see also Smith, Civic Ideals, 337-42. 
South Carolinian historian and physician David Ramsay, for instance, considered the difference between British subjects and American citizens "immense" because, whereas subjects had to bow to a master, citizens were free and "collectively" held sovereignty. "Each citizen of a free state contains, within himself, by nature and the constitution," Ramsay wrote, "as much of the common sovereignty as another." He also assumed that citizenship included the right to vote. ${ }^{10}$

Such a participatory view of citizenship had not disappeared by the midnineteenth century. Dictionaries' definitions of a "citizen" at the time were far more inclusive than the Supreme Court's. Webster's American Dictionan of the English Language defined a citizen in the United States as "a person, native or naturalized, who has the privilege of exercising the elective franchise." Similarly, Worcester's Dictionary of the English Language saw a citizen as "an inhabitant of a republic who enjoys the rights of a citizen or a freeman, and who has a right to vote for public officers." Law dictionaries, too, erred in this direction: both Burrill's New Law Dictionary and Glossary and Bouvier's Law Dictionary gave as the first definition of citizen in American law, "One who, under the constitution and laws of the United States, has a right to vote for public officers, and who is qualified to fill offices in the gift of the people." 20 Justice Taney corroborated that view when he asserted in the Dred Scott decision, "The words 'people of the United States' and 'citizens' . . both describe the political body who ... form the sovereignty, and who hold the power and conduct the Government through their representatives."21

${ }^{19}$ David Ramsay, A Dissertation on the Manner of Acquiring the Character and Privileges of a Citizen of the United States (Charleston, [S.C.], 1789), quoted in Gordon S. Wood, The Radicalism of the American Revolution (New York, 1992), 169; and further quoted in Smith, Civic Ideals, 154.

${ }^{20}$ Lucie, "On Being a Free Person," 356, cites a speech of A. G. Riddle before the House Judiciary Committee, January 11, 1871, examining dictionary definitions, which led me to do the same. See entries under "citizen" in Noah Webster, An American Dictionary of the English Language (New York, 1830), (Springfield, Mass., 1850), and (Springfield, Mass., 1881); Joseph E. Worcesier, A Dictionary of the English Language (Boston, 1860, 1886); Alexander Burrill, A New Law Dictionary and Glossary (New York, 1850); John Bouvier, A Law Dictionany. vol. 1 (Philadelphia, 1868), and (Boston, 1897). The law dictionaries also cite additional minimal definitions, such as "A free inhabitant, born within the United States, or naturalized under the law of Congress" (Burrill's); "Any white person horn in the United States, or naturalized person born out of the same, who has not lost his right as such,-—including men, women, and children" (Bouvier's, 1868); "All persons born or naturalized in the United States, and subject to the jurisdiction thereof" (Bouvier's, 1897). The Webster's definitions show an interesting evolution. The 1830 edition adds to the phrase quoted in text "and of purchasing and holding real estate" (distinguishing the citizen from the alien's common-law disabilities regarding real property); the 1850 edition adds "or the qualifications which enable him to vote for rulers, and to purchase and hold real estate": the 1880 edition phrases the definition for the United States as "A person, native or naturalized, who has the privilege of voting for public officers, and who is qualified to fill offices in the gift of the people" and then adds (perhaps as a result of Minor v. Happersett) the new phrase, "also, any native born or naturalized person, of either sex, who is entitled to full protection in the exercise and enjoyment of the so-called private rights."

2 Justice Taney had to hedge, however, lo encompass women's citizenship: "Undoubtedly, a person may be a citizen, that is, a member of the community who form the sovereignty, although he exercises no share of the political power, and is incapacitated from holding particular offices. Women and minors, who form a part of the political family, cannot vote: and when a property qualification is required to vote or hold a particular office, those who have not the necessary qualitication cannot vote or hold the office, yet they are citizens." Dred Scott 1. Sanford, 60 U.S. (19 How.), 393, 404, 422. The case most often cited as defining the privileges and immunities of citizenship in the first half of the century was Corfield v. Coryell, $6 \mathrm{~F}$., Cas 546 (C.C.E.D. Pa., 1823), in which these were said to encompass only fundamental (civil) rights. the last phrase of the description being, however, "to which may be added the elective franchise, as regulated and established by the laws or Constitution of the State in which it is to be exercised." 
IF SOVEREIGNTY, POWER, AND CONDUCTING THE GOVERNMENT were the attributes of citizenship, then there was more than a single operative understanding of it. The minimal definition stood, equivalent to "American national." That citizen might be a white woman, a propertyless white man (early in the century), a child, and by some lights, a free African American of either sex. The other conception of the citizen was the reigning figure in political discourse: the person who belonged to the nation and had the independence and virtue to participate fully as a voter. It was the latter conception, surely, that Thomas Jefferson had in mind when he wrote to a friend in 1776 that he favored "extending the right of suffrage (or in other words the rights of a citizen) to all who had a permanent intention of living in the country. Take what circumstances you please as evidence of this, either the having resided a certain time, or having a family, or having property, any or all of them." In including the vote among "the rights of a citizen" and not limiting its exercise to those who had property but taking "proxies" for property, such as heading a family, Jefferson was more democratically oriented than many revolutionaries; at the same time, his reference to "having a family" indicates that he envisioned the citizen to be an adult (white) male. 22

We might call the one conception nominal or minimal citizenship and the other participatory citizenship. What enabled a move along the spectrum from one to the other? This question follows the lead of T. H. Marshall's classic essay of 1950 . Inquiring whether citizenship in Britain signified anything when steep property qualifications kept most men from voting, Marshall contended that "citizenship in this period was not politically meaningless" even for those men disfranchised by lack of property. "It did not confer a right, but it recognized a capacity." A citizen was distinguished by the unencumbered personal status and civil rights that enabled him to acquire property and thus attain a voter's qualification. In Marshall's terms, the right to vote came as a "secondary product of civil rights."23

Marshall's view that what he called "political citizenship" flowed from "civil citizenship" would not have been unfamiliar to American legislators a century earlier. The political vocabulary of that time distinguished four categories of rights. The matrix was "natural" rights, the rights to personal security, liberty, and the pursuit of property that governments should not invade but protect. To guarantee these natural rights, an individual needed "civil" rights, which centered on the contractual powers to manipulate property and protection of the laws. "Political" rights indicated full participation in governance, most important, voting, being able to hold office, serve on a jury and in the military. And "social" rights-a vaguer and more contested category-were in the domain of social relations, such things as choice of friends and intimates as well as business associates, generally seen as not directly susceptible to legislation. ${ }^{24}$

22 Jefferson quoted in Joan Gunderson, "Independence, Citizenship, and the American Revolution," Signs 13 (Autumn 1987): 59-77, on 64; see Linda K. Kerber, Women of the Republic: Intellect and Ideology in Revolutionary America (Chapel Hill, N.C., 1980), esp. 13-32, 137-56; Gordon S. Wood, The Creation of the American Republic, 1776-1787 (New York, 1969), 168-69; Joan Hoff, Law, Gender, and Injustice: A Legal History of U.S. Women (New York, 1991), 80-81, 90-94.

${ }_{23}$ Marshall and Bottomore, Citizenship and Social Class, 13, emphasis added.

${ }^{24}$ Eric Foner, Reconstruction: America's Unfinished Revolution, 1863-1877 (New York, 1988), 231; Mark Tushnet, "The Politics of Equality in Constitutional Law: The Equal Protection Clause, Dr. Du Bois, and Charles Hamilton Houseton," Journal of American History 74 (December 1987): 886-89; 
When Congress grappled with the political status of the ex-slaves at the end of the Civil War, the relationship between political and civil rights became very pressing. As early as 1862 , Republicans contemplating emancipation found themselves having to fend off the notion that freeing the slaves-making them citizens-meant endowing them with the powers to vote and hold office. Representative John Bingham of Ohio was exasperated with hearing "constantly reiterated" the belief that citizenship itself brought about political rights. Aiming to pass the Civil Rights Bill of 1866 to secure legal access and the rights of frue laborers and property holders for ex-slaves, Republicans in Congress emphasized that those, and not the vote, were the basic rights composing American citizunship. Lyman Trumbull of Illinois soothed Senate colleagues hostile to the idea of enfranchising freedmen with the contention that "the granting of civil rights does not, and never did in this country, carry with it ... political privileges." Trumbull was interpreting the Constitution correctly-that is, in accord with what the Supreme Court would say in Minor vs. Happersett--which makes it all the more interesting that an alternative view resolutely persisted: that if citizenship was not exactly equivalent to political privileges (as in the dictionaries), the two were inherently related, and the one led directly to the other. The Delaware Democrat Willard Saulsbury, for example, opposing the Civil Rights Bill in the Senate, exclaimed, "Talk to me, Sir, about the words 'civil rights' not including the right to vote. What is a civil right? It is a right that pertains to me as a citizen. And how do I get the right to vote? I get it by virtue of citizenship and I get it by virtue of nothing else. When this act is passed into a law and I find a Republican judge in any of the States of this country deciding under it a negro has the right to vote, I am not going to quarrel with the opinion of that judge, because I believe he is deciding the law corsectly." 25

Saulsbury's assumption accorded with T. H. Marshall's generalization that civil rights showed or gave "capacity" for full political citizenship. Yet Marshall's typology, suggesting a clear category of those citizens with civil rights only, capable of graduating into the latter category by means of some accomplishment like amassing property, is too simple actually to express the situation in nineteenthcentury America, where civil and political rights were unevenly and inconsistently allocated. Not every citizen who lacked the vote lacked all political rights (or obligations): men disfranchised by property requirements were called to serve in state militias, for example. And not every citizen who voted thereby had all political rights: even after the Fifteenth Amendment attempted to protect black men's right

Morais, "Sex Discrimination," 1157-58; Sandra Rierson, "Race and Gender Discrimination: A Historical Case for Equal Treatment under the Fourteenth Amendment," Duke Joumal of Gender Law and Policy 1 (1994): $111-14$; Robert J. Kaczorowski, "To Begin the Nation Anew: Congress, Citizenship, and Civil Rights after the Civil War," AHR 92 (February 1987): 48 49; see also Reva Siegel, "Why Equal Protection No Longer Protects: The Evolving Forms of Status-Enforcing State Action," Stanford Law Review 49 (May 1997).

${ }_{25}$ Bingham, in discussion of emancipation of District of Columbia slaves, Congressional Globe, 37 th Cong., 2d sess. (April 11. 1862), 1639: Trumbull, in debate on the Civil Rights Bill of 1866, Congressional Globe, 391h Cong., Ist sess. (April 4, 1866), 1757; Saulsbury quoted in Lucie, "On Being a Free Person," 357. Lucie also makes the point that woman suffragists and Democrats showed a "wider interpretation of citizenship." Sen. Saulsbury tried to add to the specification of civil rights in the 1866 bill the phrase "except the right to vote in the States"; Congressional Globe. 39th Cong., 1st sess. (February 2, 1866), 606. 
to vote, their right to serve on juries was contested in courts for decades. Similarly, when the Nineteenth Amendment eliminated sex as a bar to voting, many states still refused to allow or require women to serve on juries, and no women were called to the armed services. On the other hand, alien men have been called to serve in the armed forces, as a route to rather than a consequence of citizenship, but not on juries. And some aliens-white male immigrant declarants in generous states-who would not be defended by the State Department if abroad, nonetheless wielded more rights and had more access to political participation at home than native-born women citizens. ${ }^{26}$

These inconsistencies, along with the importance in political discourse of the figure of the participatory citizen, may have reinforced the ideological presumption that the citizenship of aspiration was open to all. ${ }^{27}$ The immediate post-Civil War years underlined that presumption. If Republican leaders in Congress initially hardened the distinction between civil rights and political privileges, they then moved to merge the two in the freedmen's possession. The quick progression from the 1866 Civil Rights Bill to the Fourteenth and then the Fifteenth Amendments seemed ironically to confirm Saulsbury's Democratic view that the polity of the United States provided irresistible momentum for continuity between citizenship and political rights. Woman suffragists, who were inspired at the time by the Radical Republicans' ending of slavery and extension of civil rights and voting to freedmen, certainly interpreted the progression this way. In the "New Departure" of 1871-1873, woman suffragists acted on the view that citizenship included voting rights, and they went to the polls and voted. It was in answer to such a suffragist's claim that the Supreme Court arrived at the "membership" definition of U.S. citizenship. Virginia Minor had tried to register to vote in Missouri in 1872 on the theory that there was no such thing as "halfway citizenship"-that the Fourteenth Amendment's statement of her citizenship empowered her (and women generally) to vote. A unanimous court disagreed, pointing to the separate states' prerogative to control voting privileges, insisting that women were citizens of the nation but equally strongly that national citizenship did not give them political rights. ${ }^{28}$

When Republicans like Bingham and Trumbull had, prior to 1866 , emphasized that civil rights or citizenship would not automatically bring along political rights to the freedmen, their premier example was the half of the white adult population who

${ }^{26}$ Kerber, "Meanings of Citizenship," 836-37; on militias, see Alexander Keyssar, A History of the Right to Vote, forthcoming (ms. in author's possession), chap. 2; on African-American jury service, see U.S. v. Reese, U.S. v. Cruikshank, 92 U.S. 542 (1876); Strauder v. West Virginia, 100 U.S. 303 (1879); Virginia v. Rives, 100 U.S. 313 (1879); Ex parte Virginia, 100 U.S. 337 (1879); Civil Rights Cases, 109 U.S. 3 (1883); on women and juries, see Jennifer Brown, "The Nineteenth Amendment and Women's Equality," Yale Law Journal 102 (1993): 2175-2204; and Blayne H. Cutler, "When Women Became Peers: A Century's Struggle for Equal Jury Access in America, 1870-1975" (PhD dissertation, Yale University, 1996); Kerber, No Constitutional Right, chap. 4. An example of military service bringing citizenship is the law of 1919 granting citizenship to Indian veterans of World War I; Arnold J. Lien, The Acquisition of Citizenship by the Native American Indians, Washington University Studies, vol. 13, Humanistic Series, no. 1 (1925), 175-76; on alien suffrage, see note 15 above.

${ }^{27}$ I adapt this phrase from Hendrik Hartog, "The Constitution of Aspiration and 'The Rights That Belong to Us All," Joumal of American History 74 (December 1987): 1013-34.

${ }^{28}$ See DuBois, "Outgrowing the Compact," 836-62; and "Taking the Law into Our Own Hands: Bradwell, Minor, and Suffrage Militance in the 1870s," in Nancy A. Hewitt and Suzanne Lebsock, eds., Visible Women: New Essays on American Activism (Urbana, Ill., 1993), 19-40; Minor v. Happersett, 88 U.S. (21 Wall.), 162. 
were citizens without voting or holding office: women. ${ }^{29}$ This example had a unique force, since congressmen wanted neither to see their "wives and mothers and daughters" deemed noncitizens nor to invest them with political rights. The example enforced awareness that some citizens never graduated to political rights, without stating it just this way. The gender difference was not made explicit, although it was crucial. ${ }^{30}$ It was also not explicit in the Minor vs. Happersett opinion, enabling the court-against Virginia Minor's intent-to legitimate "halfway" citizenship, which would soon be used to warrant black men's exclusion from juries. ${ }^{31}$

WOMEN'S CITIZENSHIP THUS BECAME A TOUCHSTONE to justify less-than-participatory citizenship, and in this connection marriage was central. The institution of marriage required the wife to serve and obey her husband - to become his dependent-as he was to support and protect his wife. Participatory citizenship in the American political tradition required the opposite, however: independence. Drawing on their British heritage, revolutionary spokesmen had highlighted personal independence as necessary to public virtue and political rights. Independence meant freedom of judgment-freedom from the imposition of the will of another-and in the eighteenth century that meant heading a household and owning property of one's own so as not to have to look to anyone else for a job, credit, or support. "The independent man was, almost by definition, a head of household," Toby Ditz has underscored (summarizing the findings of many historians of early America): "independence did not refer to the abstract autonomy of persons. Rather, it was founded on a clear hierarchy as the privilege of men occupying the status of household head." 32

${ }^{29}$ My thanks to Akhil Amar for shrewd pointers on this issue. See, for example, Bingham, Congressional Globe, 37th Cong., 2d sess. (April 11, 1862), 1639, stating that if there were anything to the argument that citizens' rights were dependent on political rights, then "your wives and mothers and daughters ... are not to be considered as invested with the rights of citizenship"; Trumbull, in debate on the Civil Rights Bill of 1866, Congressional Globe, 39th Cong., 1st sess. (April 4, 1866), 1757; other examples in this debate include remarks of Rep. James Wilson of Iowa (March 1, 1866), 1117; Rep. William Windom of Minnesota (March 2, 1866), 1159; Sen. Henry Wilson of Massachusetts (March $7-8,1866), 1255$.

30 A generation of feminist scholars has now shown that the civil and political subject in the Western political tradition (and no less in T. H. Marshall's work) has been implicitly a man, a male head of household. See especially Susan Moller Okin, Women in Western Political Thought (Princeton, N.J., 1979); and Carole Pateman, The Sexual Contract (Stanford, Calif., 1988), on the "sexual contract" prior to and embedded in the modern Western political tradition's foundational social contract ideology. Fraser and Gordon, in "Civil Citizenship against Social Citizenship?" 94-95, also note that Marshall did not discern how far the "individual" of whom he spoke was male, his independence based on the dependence of his wife.

31 See jury cases named in note 26 above.

32 The social order depended on what Ditz calls "household patriarchy," that is, household heads were responsible for the well-being of their dependents (family members, servants, apprentices, slaves), had the formal authority to make decisions for them, and represented them to the larger world. Toby L. Ditz, "Ownership and Obligation: Inheritance and Patriarchal Households in Connecticut, 17501820," William and Mary Quarterly, $3 \mathrm{~d}$ ser., 47 (April 1990): 256. 236-37; Tomlins, "Subordination, Authority, Law," 73-74; Jack P. Greene, All Men Are Created Equal: Some Reflections on the Character of the American Revolution (Oxford, 1976), 20-23: Wood, Creation of the American Republic, 168-69. Greene points out that most categories of people excluded from voting in the American colonies before the revolution were seen to be dependents: they included wives, minors, servants and slaves, soldiers 
Independence in this sense for the male household head existed in counterpoint to the dependence of others. Having and supporting dependents was evidence of independence. Thus marriage as well as property empowered a man in civic status, showing his capacity for citizenship by making him head of a household. To be a husband was to command the personal and material resources of a household and therefore to deserve a voice in the polity. ${ }^{33}$ Statesmen likened married status to property holding as evidence of men's suitability for political participation. During the debate on the Constitution, George Mason proposed that a husband and father might qualify for the vote even if not a landholder, asking rhetorically, "Ought the merchant, the married man, the parent of a number of children . . . be viewed as suspicious characters and unworthy to be trusted with the common rights of their fellow citizens?" This orientation persisted into the nineteenth century, as evidenced by a proposal at the 1850 Maryland state constitutional convention "that every married man above the age of 18 years, and having the above qualifications of residence shall be entitled to the right of suffrage." 34

In corollary, marriage made women into dependents. There was no middle ground here: either one was independent and had the capacity to have dependents or one was dependent on someone else. The coverture of married women in the Anglo-American common law represented and perpetuated this polarity. ${ }^{35}$ In making a woman a wife, marriage removed from her and transferred to her husband her property and income, the very items that indicated free will. The property cession both symbolized and operationalized a husband's independence and his wife's (economic) dependence and consequent civic disability. The husband was not

and sailors, Catholics (dependent on the church), tenants and renters. See also J. G. A. Pocock, "Machiavelli, Harrington and English Political Idcologies in the Eighteenth Century," William and Mary Quarterly, 3d ser., 22 (October 1965): 549-83, on the English thinkers to whom Americans were indebted in their stress on personal independence.

33 Indeed, the antique meaning of "husband" was a male head of household, a master of a house, a freeholder owning his own house and land; see Oxford English Dictionary; and John R. Gillis, For Better, for Worse: British Marriages, 1600 to the Present (New York, 1985), 57. On the revolutionary rhetoric of dependence and independence, see Gunderson, "Independence, Citizenship and the American Revolution"; Jay Fliegelman, Prodigals and Pilgrims: The American Revolution against Patriarchal Authority, 1750-1800 (Cambridge, 1982). Gunderson emphasizes that the American Revolution, with its anti-patriarchal rhetoric and rejection of childlike colonial dependency on an imperial parent, tended to enhance the manly connotations of independence and strengthen the pejorative connotations of dependence. Greene, All Men Are Created Equal, 20-23, even suggests that the operative word in the Declaration of Independence phrase "all men are created equal" may be "men," as an equivalent for citizens. Compare Fraser and Gordon's (Patemanesque) view that, "With the construction of modern civil society ... married men who would have earlier been 'dependents' within larger patriarchal units became family 'heads' and 'individuals.' Family headship thus became a newly salient and honorific status, ... a source of civil citizenship ... [T]he exclusion of married women from civil citizenship was no mere archaic vestige destined to fade as citizenship evolved. Rather, women's subsumption in coverture was the other face and enabling ground of modern civil citizenship. The two mutually defined one another." Fraser and Gordon, "Civil Citizenship against Social Citizenship?" 97.

${ }^{34}$ George Mason quoted in Mark E. Kann, On the Man Question: Gender and Civic Virtue in America (Philadelphia, 1991), 198; I am indebted to Alexander Keyssar for the quotation from Proceedings of the Maryland State Convention to Frame a New Constitution, November 4, 1850 (Annapolis, Md., 1850 ), 136. Likewise, Nathaniel Macon of North Carolina in 1802 told an Ohio politician that he believed every married man, freeholder or not, should vote; cited in Chilton Williamson, American Suffrage: From Property to Democracy, 1760-1860 (Princeton, N.J., 1960), 223.

${ }_{35}$ Linda K. Kerber, "A Constitutional Right to Be Treated Like American Ladies: Women and the Obligations of Citizenship," in Kerber, U.S. History as Women's History, 20-23, is the best recent discussion of coverture. 
seen as expropriating his wife but as getting recompense for supporting, protecting, and representing her: marriage was understood as a reciprocal bargain arising from consent.

Of course, ownership of property did not persist as a prerequisite for political participation. Almost all the states had eliminated the property requirement for voting by 1850 . Yet the qualifying criterion of "independence" remained in the norm of white manhood suffrage that increasingly succeeded it. As Robert Steinfeld has shown, in the early nineteenth century two contending principles for defining independence coexisted in political arguments. The assumption that tangible wealth or property was necessary to indicate independence hung on, but it was increasingly met by the claim (more suitable to a commercial and industrial economy) that independence inhered in the self-governing individual who could dispose of his own labor profitably. Steinfeld finds a contrast between the wage earner and the pauper instrumental in defining independence in the newer sense. State constitutions granting white manhood suffrage also excluded paupers. The pauper who sought public relief, being "thrown on the town," did not freely command his own labor. Steinfeld emphasizes that this lack, along with the enforced bond of legal dependence, defined the pauper as not independent. ${ }^{36}$

The model for the pauper's dependence lay in domestic relations. If the essence of the pauper's lack of self-governance was his inability to dispose of his own labor, the same was true of the wife's position. By the marriage contract, the wife owed her labor to her husband. ${ }^{37}$ This principle persisted in the law (as well as culturally) long after coverture was supposedly a dead letter. By 1850 , virtually cvery state had passed a statute stipulating that a married woman owned her own property. State statutes securing wives' own earnings to them, often passed under pressure from women's rights advocates, followed after the Civil War. Yet well into the twentieth century, judges refused to see wives as owners of the value of their domestic labor because to do so would contravene their very wifehood. ${ }^{3 *}$

The shift from property ownership to self-command of labor as the cardinal indication of "independence" may have been instrumental in fixing all women, not only wives, in a position of minimal citizenship. During the eighteenth century, there were occasional episodes in which women's ownership of property warranted

\footnotetext{
36 Robert J. Steinfeld, "Property and Suffrage in the Early American Republic," Stanford Law Review 41 , no. 2 (1989): 335-76.

${ }^{37}$ Steinfeld acknowledges, "Property and Suffrage," 345, that "the relation of towns to their 'paupers,' was structured in exactly the same way as the relationship of heads of household to their dependents. Both were reciprocal relationships in which one party owed a duty of support and the other owed a duty of loyalty and service in return." Compare Nancy F. Cott, "Divorce and the Changing Status of Women in Eighteenth-Century Massachusetts." William and Mary Quarterly, 3d ser., 33 (October 1976): 611-13; Reva Siegel, "Home as Work: The First Woman's Rights Claims Concerning Wives' Household Labor, 1850-1880," Yale Law Journal 103 (March 1994): 1082-85; Tomlins, "Subordination, Authority, Law."

${ }^{3 *}$ See Norma Basch, "Invisible Women: The Legal Fiction of Marital Unity in Nineteenth-Century America," Feminist Studies 5 (Summer 1979): 346-66; and Basch, In the Eyes of the Law: Women. Marriage and Property in Nineteenth-Century New York (Ithaca, N.Y., 1982); Richard H. Chused, "Married Women's Property Law: 1800-1850," Georgetown Law Joumal 71 (June 1983): 1359-1425; Amy Dru Stanley, "Conjugal Bonds and Wage Labor: Rights of Contract in the Age of Emancipation," Journal of American History 75 (September 1988): 471-500: Reva B. Siegel, "The Modernization of Marital Status Law: Adjudicating Wives' Rights to Earnings, 1860-1930," Georgetown Law Journal 82 (September 1994): 2127-2211.
} 
their political participation. The most compelling example is in New Jersey, where the state constitution of 1776 included propertied women along with propertied men in the franchise. Enabling statutes in 1790 using the pronouns "he or she" and "his or her" reiterated the inclusion of women, which was not reversed until $1807 .{ }^{39}$ Since property ownership was concrete, some single women and widows could show evidence of it, palpably distinguishing themselves from wives under coverture. But the tie of married women's labor to unpaid household service affected all women, undermining the independent potential of all women's labor and causing it to be undervalued if acknowledged at all. In New England, this fact registered in the 1820-1850 period of initial industrialization in the disparate wage rates paid to male and female operatives. In 1850, women wage earners averaged about half of men's earnings, and that gender differential persisted for more than a century. ${ }^{40}$

Women wage earners' lack of economic opportunity was one translation of the expectation that they would be wives and have their labor commanded. All women's lack of political rights was another, expressing the absence of self-command inherent in the bargain the wife made. As Reva Siegel has shown, speakers at early women's rights conventions understood this link when they insisted that wives' unpaid domestic labor entitled them to half the marital assets. ${ }^{41}$ Male delegates to constitutional conventions throughout the mid-nineteenth century assigned married women, widows, and single women all to "the self-same boat of dependency," Rowland Berthoff has found. Politicians found justification in "natural laws," which supposedly prescribed weakness, diffidence, and strictly domestic "capacities" for women. They left unsaid how profoundly the labor/dependency relations of marriage influenced their understanding of "nature." 42

39 The New Jersey Constitution of 1776 extended the franchise to all inhabitants residing more than one year who were worth $£ 50$. I have learned a great deal on this topic from Elizabeth Walker Brundige, "'To Have a Fair Election': Women's Suffrage in Republican New Jersey," unpublished senior essay, Yale College, April 13, 1998 (in my possession); compare Judith Apter Klinghoffer and Lois Elkis, "'The Petticoat Electors': Women's Suffrage in New Jersey, 1776-1807," Journal of the Early Republic 12 (Summer 1992): 159-94.

40 Richard Chused makes this summary point on women's industrial wages in "Married Women's Property Law," 1363. Edith Abbott's classic Women in Industry (New York, 1910) is still a good place to begin on the history of women in early industrial employment in the United States. On the devaluation of housewives' labor, see Jeanne Boydston, Home and Work: Housework, Wages, and the Ideology of Labor in the Early Republic (New York, 1990).

4 ' Siegel, "Home as Work."

${ }^{42}$ Berthoff, "Conventional Mentality," 760. Stephanie McCurry argues for the importance in "large politics" of antebellum South Carolina yeoman farmers' identity as husbands and fathers in Masters of Small Worlds: Yeoman Households, Gender Relations and the Political Culture of the Antebellum South Carolina Low Country (New York, 1995); her approach would suggest that, as husbands, men in politics in the nineteenth century had an implicit stake in keeping women politically disfranchised. On men's intensifying insistence on women's "natural" dependence, see Steinfeld, "Property and Suffrage," esp. 356-57; compare Jacob Katz Cogan, "The Look Within: Property, Capacity, and Suffrage in Nineteenth-Century America," Yale Law Journal 107 (November 1997): 473-98. See Nancy Leys Stepan, "Race, Gender, Science and Citizenship," Gender and History 10 (April 1998), esp. 30-31, on the emphasis of Enlightenment science and rationality on "natural" origins of distinctions among groups of humans.

If most men in political life assumed that women were "naturally" non-self-governing, economically and politically, that does not mean that all women (married or not) saw themselves that way. Between the 1830s and the Civil War, some women loudly insisted on their public personae and made use of the resources of the law and public policy available to them (such as the courts and petitions). The small minority who demanded the right to vote expressed feeling deprived rather than non-deserving. For examples, see Jacob Katz Cogan and Lori D. Ginzberg, "1846 Petition for Woman's Suffrage, New 
THE LEGAL NORM OF A WIFE'S DEPENDENCE on her husband did not rule everywhere, though: it did not reach her national citizenship. For three-quarters of a century after the American Revolution, a woman's hold on her nationality appeared to be about the same as a man's, not directly affected by marriage or coverture. This was a legacy of the British common-law insistence on indelible nationality. It was a common-law principle also that the husband's place of residence determined the marital domicile; but, in numerous antebellum cases, noncitizen women who had married American men were unable as widows to gain dower rights in land in the United States, because they were aliens. "The alien widow of a citizen cannot be endowed" (that is, receive dower) was the doctrine, which some states began to subvert by passing statutes alleviating the unfriendliness of the common law to alien property holding. A woman immigrant could become a naturalized citizen in the United States while married to a noncitizen man. Her relation to the state had its own integrity, according to antebellum judges, one of whom did not doubt "that Congress possess [sic] the power to naturalize femes covert, even against the consent of their husbands." 43

A Supreme Court decision of 1830 , Shanks vs. Dupont, confirmed that marriage to a foreigner did not ipso facto contravene an American woman's allegiance. Justice Joseph Story wrote that "marriage with an alien . . produces no dissolution of the native allegiance of the wife. It may change her civil rights, but it does not effect [sic] her political rights or privileges." In using the term "political rights," Story was not referring to the right to vote or hold office but rather to national identity. That became clear in his discussion of the ability of the woman in question, Ann Shanks, to change her national allegiance by moving from South Carolina to Britain with her British husband in 1782. Story maintained that her change of allegiance from America to Britain emanated from her own choice of taking up residence in Britain and "adhering to the British side," and the British crown's accepting her, not from her marriage to a British husband. "It does not appear to us that her situation as a feme covert disabled her from a change of allegiance," he wrote. "The incapacities of femes covert, provided by the common law, apply to their civil rights, and are for their protection and interest. But they do not reach

York State Constitutional Convention," Signs 22, no. 2 (1997): 427-39; Dianne Avery and Alfred S. Konefsky, "The Daughters of Job: Property Rights and Women's Lives in Mid-Nineteenth Century Massachusetts," Law and History Review 10 (Fall 1992): 350-56; Siegel, "Home as Wurk." Demands for the vote were only a small part of women's modes of possible political, legal, or civil participation; see Michael Grossberg, A Judgment for Solomon: The D'Hauteville Case and Legal Expericnce in Antebellum America (New York, 1996); and Norma Basch, "Relief in the Premises: Divorce as a Woman's Remedy in New York and Indiana, 1815-1870," Law and History Review 8 (Spring 1990): 1-24, for examples of married women making use of their civil rights and all feasible legal resources to address the family issues of child custody and marital break-up.

4.3 Quotation from opinion by Samuel Nelson, Chief Justice of the New York Supreme Court of Judicature in Priest and Others v. Cummings, 16 Wend. 617 (N.Y., 1837). See also Kelly v. Harrison, 2 Johns. Cas. 29 (N.Y., 1800); Ex parte Marianne Pic, 1 Cranch C.C. 372 (D.C., 1806); Sutliff v. Forgey, 1 Cowen 89 (N.Y., 1823); Alsberny v. Hawkins, 9 Dana 177 (Ky., 1830); Mick v. Mick, 10 Wend. 379 (N.Y., 1833); Davis v. Darrow, 12 Wend. 65 (N.Y., 1834); Connolly v. Smith, 21 Wend. 59 (N.Y., 1839); Trimbles v. Harrison, 1 B. Mon. 140 (Ky., 1840); Moore v. Tisdale. 5 B. Monroe 352 (Ky., 1845); Currin v. Finn, 3 Denio 229 (N.Y., 1846); Beck v. McGillis, 9 Barb. 35 (N.Y., 1850); Brown v. Shilling, 9 Md. 74 (1856); Greer v. Sankston, 26 How. Pr 471 (N.Y., 1858); Waltz. Nationality of Married Women, 18-23; J. Scott, et al., Citizenship of the United States, Expatriation, and Protection, 29-30, 102, 145-51; Kettner, Development, 272-74. 
their political rights, nor prevent their acquiring or losing a national character. Those political rights do not stand upon the mere doctrines of municipal law, applicable to ordinary transactions, but stand upon the more general principles of the law of nations." The central claim, reliant on the British common law of indelible nationality, and Story's inference that the government has to involve itself positively in a change of allegiance, was that marriage itself did not-could not-alter a woman's membership in a national polity. ${ }^{44}$

In 1855, however, Congress overrode this longstanding approach by passing a statute declaring that any woman who had married or would marry an American man gained American citizenship in doing so. The act was remarkable in its gender specificity, giving a particular privilege to American male citizens only. It underlined customary male headship of the marital couple as a civic and political norm. The same statute affirmed the American citizenship of children born abroad to U.S. citizen fathers, not to mothers (although an earlier version had proposed both) ${ }^{45}$ Making the wife's and children's nationality dependent on the male citizen's, the law increased his privileges while limiting his wife's arena of political choice. A congressional sponsor, Democrat Francis Cutting of New York, explained the law's intention: "by the act of marriage itself the political character of the wife shall at once conform to the political character of the husband." This made the foreignborn wife's consent to marry her definitive act of political consent. She would relate to the state through her husband as intermediary, as John Milton had written of the sexes' relation to a higher authority: "He for God only, she for God in him." 46 In Representative Cutting's view, "women possess[ed] no political rights" to be

${ }^{44}$ Shanks v. Dupont, 3 Pet. 242 (1830), 246-48; Waltz, Nationality of Married Women, 18-23; Kettner, Development, 187-89, and passim on the differences between British and American notions of citizenship in the early republic. Linda Kerber's searching treatment of Martin v. Commonwealth, 1 Mass. Rep. 347 (1805), "Paradox of Women's Citizenship," which argues that the (unsuccessful) position taken on behalf of Anna Martin's autonomous nationality showed revolutionary possibility, does not fully consider the doctrine preceding and surrounding Martin. (Likewise her discussion in "Constitutional Right," 27-28.) The recorded cases are few, but the two cases closest to Martin (Pic and Kelly v. Harrison-see previous note) recognized a feme covert's nationality to be separate from her husband's, and a following Massachusetts case, Sewall v. Lee, 9 Mass. Rep. 263 (1812), implied the same although a decision on that point was not actually made. All this suggests that the Martin decision diverged from the foregoing norm (separation of marital status from citizenship), which Shanks v. Dupont later articulated at the Supreme Court level, rather than Martin enunciating a norm of the early republic that Shanks advanced beyond, as Kerber has it. This is not to say that the principle of a wife's autonomy as such was vigorous in the early republic: in the Shanks norm, the common law of perpetual nationality weighed more, while in practice at the time the inchoate character of national citizenship and the relative importance of state citizenship in which marital domicile was determined by the husband likely did.

45 The initial impetus for the bill was concern about the citizenship of children born abroad to American fathers. A drafting defect had been discovered in the 1802 law supposed to deem such children citizens. Representatives aiming to correct that defect added the clause making citizens of American men's wives. Resisted at first, the clause was eventually accepted by the Senate. Congressional Globe, 33d Cong., 1st sess. (January 13, 1854), 169-71; Congressional Globe, 33d Cong., 2d sess. (December 20, 1854, December 21, 1854, February 8, 1855), 91-92, 116, 632, 651. Franklin, Legislative History of Naturalization, 271-74; Seckler-Hudson, Statelessness, 199-202; Burton v. Burton, 26 How. Pr. (New York), 474, 477-78; J. Scott, et al., Citizenship of the United States, Expatriation, and Protection, 29-30, 145-51, 102; Bredbenner, "Toward Independent Citizenship," 2-3. The common-law disposition for free persons was partus sequitur patrem: the offspring would follow the condition (including the nationality) of the father. Kettner, Development, 14-15.

46 See Sapiro, "Women, Citizenship and Nationality," 7-11; Bredbenner, "Toward Independent Citizenship," 19-20. Compare Linda Kerber's contention, in "Constitutional Right," 22-23, that under coverture, a "woman's only freely chosen obligation was to her husband"; her husband was positioned 
infringed, so the statute was simply an aid "to the husband ... in the instilling of proper principles in his children and cannot interfere with any possible right of a political character." He used the term "political rights" not as Justice Story had but in the increasingly common way, to mean rights to share directly in governance. ${ }^{47}$

The 1855 statute accorded with the move to consider the capacity for full citizenship inherent in the self-governing man only and not in any person encumbered by bonds of dependence. It also suggested an emergent definition of male citizenship that would incorporate a man's right to his family in his self-possession. Visible in the Northern contrast of free labor with slavery, this theme blossomed in the Radical Republicans' approach to the freedmen. To set the deprivation of the male slave in sharp relief in the $1830 \mathrm{~s}$ and $1840 \mathrm{~s}$. William Lloyd Garrison had stressed that even the most wretched free laborer had his family: "Can any power take from him wife and children?" Even if degraded, the free laborer was "still the owner of his own body ... still a husband." Similarly, the New England Offering in 1848 refused to liken the free wage worker to a slave, stressing the "worth" of his "right to himself, to his family." In postwar congressional debate, Senator Jacob Howard of Michigan pointedly insisted that "the attributes of a freeman according to the universal understanding of the American people" had to include "the right of having a family, a wife, children, home." 48

Passed with no ceremony and little debate, the 1855 law took a big step, in effect raising the doctrine of coverture to the level of national identity. It was as if each male citizen who married a foreigner "annexed" and naturalized her, as the United States naturalized by treaty the inhabitants of territory conquered or purchased. ${ }^{49}$ The statute rowed against the current of married women's property acts, which mitigated coverture; but several historians have emphasized that state legislators, in declaring wives' property separate, aimed less at wives' autonomy than at the economic benefit to be gained by husbands in insulating some familial assets from creditors. ${ }^{50}$

as a "barrier between her and public obligation." John Milton. Paradise Lost, Book 4, 11. 297-99; my thanks to Sacvan Bercovitch for locating this line.

${ }^{47}$ Francis Cutting was a lawyer who served only one term in Congress. Congressional Globe, 33d Cong., 1st sess. (January 13,1854), 169-71

48 If the slave were free, The Emancipator stressed in 1835, "his earnings would be his ... his furniture, his comforts be his--his wife. his children would be his": quoted in Amy Dru Stanley, "Home Life and the Morality of the Market," in The Market Revolution in America: Social, Political, and Religious Expressions, 1800-1880, Melvyn Stokes and Stephen Conway, eds. (Charlotlesville, Va., 1996), 89,90 . In this line of argument about male citizenship, I am indebted to Stanley's analysis. New England Offering quoted in David R. Roediger, The Wage's of Whiteness: Race and the Making of the American Working Class (New York, 1991). 83: Congressional Record, 39th Cong.. Ist sess. (January 30, 1866), 504.

49 For instance, the treaties with France in 1800 regarding Louisiana, with Spain in 1819 regarding Florida, and with Mexico in 1848 regarding southwestern territories provided that the inhabitants remaining would be effectively naturilized by the annexation. Citizenship consequences of these and other treaties were discussed by Sen. Lyman Trumbull to show that conferring citizenship on ex-slaves as a class in 1866 was not unprecedented; Trumbull did not mention the act of 1855 in this connection. however. Congressional Globe, 39th Cong. 1st sess. (April 4, 1866), 1756. See Vall Dyne, Citizenship, 143-230, on annexation and naturalization by treaty.

50 Sapiro, "Women, Citizenship and Nationality." 3-4, makes the point that "citizenship and nationality [policy] in the late nineteenth and early twentieth centuries actually expanded and intensified the principle of coverture." On married women's property acts, see sources cited in note 38 and Suzanne I). Lebsock. "Radical Reconstruction and the Property Rights of southern Women," 
In international context, the 1855 act was not remarkable, for it followed similar French and British actions. The Code Napoleon had led the way in 1804, declaring that the state regarded a married woman's nationality as echoing her husband's. French women marrying foreigners and the alien wives of Frenchmen were both included. Even more important in influencing American legislation, Parliament in 1844 ruled that any woman married or to be married to a British citizen was deemed to be naturalized herself. This was a provision in the Aliens Act that expanded opportunities for naturalization more generally, moderating the ancient doctrine that citizenship required birth in the dominion. As in the U.S. Congress, Parliament's move occasioned little discussion or justification. Ominous as the statutes might seem for wives' citizenship in principle, legislators in both nations viewed them lightly, as simply translating the doctrine of marital domicile into the era of modern nation-states and elective allegiance. ${ }^{51}$

The U.S. statute of 1855 followed the British of 1844 closely in wording, with one additional proviso: racial specificity. Not every woman married to an American citizen was to become an American national, only those "who might lawfully be naturalized under existing laws." The Senate added this phrase by amendment to the original House proposition. It was a racial qualification. Since racial exclusiveness was a fundamental tenet of American naturalization policy, the wives who were welcomed into the American polity in 1855 were free white wives. Courts interpreted the word "lawfully" to pertain to "race and blood," as a New York jurist put it, being very generous in including wives who did not meet other qualifications such as age, moral character, or even residence. ${ }^{52}$ The reach of the 1855 act was extended in 1870 when persons of African descent were admitted to naturalization, through the strenuous efforts of Senator Charles Sumner. ${ }^{53}$ No Asian woman came

Journal of Southern History 43 (May 1977): 195-216; Michael B. Dougan, "The Arkansas Married Woman's Property Law," Arkansas Historical Quarterly 46 (Spring 1987): 3-26; and compare Carole Shammas, "Re-assessing the Married Women's Property Acts," Joumal of Women's History 6 (Spring 1994): 9-30, on the increasing proportion of wealth women owned later in the century as a result of such laws.

5 The Code Napoleon also stipulated, "The husband owes protection to his wife, the wife obedience to her husband." Quoted in Mary Ann Glendon, The Transformation of Family Law: State, Law, and Family in the United States and Western Europe (Chicago, 1989), 72. On European precedents, see "American Citizenship Rights of Women," Hearing before a Subcommittee of the Committee on Immigration, United States Senate, 72d Cong., 2d sess., March 2, 1933; J. Scott, et al., Citizenship of the United States, Expatriation, and Protection, 29-30; Waltz, Nationality of Married Women, 15-16; Blanche Crozier, "The Changing Basis of Women's Nationality," Boston University Law Review 14 (1934): 131; Ann Dummett and Andrew Nicol, Subjects, Citizens, Aliens and Others: Nationality and Immigration Law (London, 1990), 87-90; Clive Parry, British Nationality, Including Citizenship of the United Kingdom and Colonies and the Status of Aliens (London, 1951), 35-37, 43-46.

52 The Senate Committee on the Judiciary at first wanted to eliminate the section granting citizenship to wives but on second thought amended it. Congressional Globe, $33 \mathrm{~d}$ Cong., $2 \mathrm{~d}$ sess. (December 20 , 1854, December 21,1854 , February 8,1855$), 91-92,116,632$. On federal naturalization law, see note 13. Courts included wives who never set foot on American soil within the ambit of the 1855 act. But as Seckler-Hudson points out, Statelessness, 42-43, the State Department interpreted the act more narrowly and did not wish to protect nonresident wives and children of American citizens. See Halsey v. Beer, 52 Hun. 366 (N.Y., 1889), quotation at 368 ; see Burton v. Burton, 40 New York (1 Keyes), 359 (1864); Renner v. Muller, 44 New York Sup. Ct. (12 Jones \& S.) 535 (1879); Leonard v. Grant, 5 Fed. (C.C.) 11 (1880); Broadis v. Broadis, 86 Fed. 951 (1898); and the important preceding Supreme Court case, Kelley v. Owen, 7 Wall. (74 U.S.), 496 (1868).

53 See Broadis v. Broadis (C.C. Cal., 1898), 86 Fed. 951 (a black woman born in Canada was an American citizen because married to one). On the 1870 change, see Congressional Globe, 41 st Cong., 
within its ambit, however. Sumner could not eliminate the word "white" from the naturalization statute as he would have preferred, because of resistance by senators from western states where Chinese immigrants had settled. The presence of Chinese male laborers, who had first arrived for the Gold Rush in California in the late 1840 s and were then recruited as cheap labor to build the transcontinental railroad, fueled the prejudices and anxieties manifest in the 1870 naturalization debate. Anti-Chinese feeling soon ballooned into enactments to prevent immigration of prostitutes, contract laborers, and then all Chinese laborers. The Exclusion Act of 1882 not only reduced Chinese immigration to a trickle of specific categories of merchants, ministers, and students but also reiterated, on top of the general naturalization law, that no state or federal court should admit any Chinese to citizenship via naturalization. Chinese exclusion was reiterated in federal laws of 1892,1902 , and $1904 . .^{54}$

The act of 1855 fell in with the aim to restrict Chinese infiltration of the American body politic, not so much by failing to make Chinese women into American wives as by holding a threat over American women who might marry Chinese men. The Chinese population in America showed no surplus of marriageable women: among the more than 100,000 Chinese residents in 1880 , the sex ratio was drastically skewed toward men, possibly the most skewed of any immigrant group at any time in the nation's history. ${ }^{55}$ What were the consequences for an American woman citizen who married a foreigner? Was she regarded as having divested herself of American citizenship? The act of 1855 was silent on this question, and cases were being decided-inconsistently-during the decades when

2d sess. (July 2, 1870, July 4, 1870), 5114-25, 5148-77; Fredrickson, White Supremacy, 145; Edward P. Hutchinson, Legislative History of American Immigration Policy 1798-1965 (Philadelphia, 1981), 57-61; James Harrison Cohen, "A Legal History of the Rights of Immigrant Aliens in the United States under the Fourteenth Amendment to the Constitution, 1870 to the Present" (PhD dissertation, New York University, 1991), 27. Although native Americans did not come within the racial limitations of the naturalization law, Hatch v. Ferguson, 57 Fed. 959 (1893), cited the 1855 law to declare that a native American woman who had married a white Anerican, left her tribe, and "adopted the habits of civilized life" thereby became an American citizen. In 1888 (after the Dawes Severalty Act), Congress passed a bill declaring that every woman member of any Indian tribe in the United States (except the five so-called "civilized tribes") who thereafter married a citizen would become a citizen herself, by marriage. (It remains unclear to me why the judge in Hatch did not cite the latter instead of the 1855 law.) Rather than being especially interested in making citizens of Indian women by means of this law, Congress hoped to keep American men who married lindian women from claiming exemption from U.S. jurisdiction. See Van Dyne, Citizenship, 121: "Report of the Secretary of the Interior," 49th Cong., 1st sess., 1885-86, House Executive Documents, vol. 11: 28-30; "Marriage between White Men and Indian Women," 50th Cong., Ist sess., H.R. Report No. 250, House Reports (1887-88); Cangressional Record 19, 50th Cong., lst sess., 1887-88, 87, 256, 512, 1024, 6885, 6903.

54 There is an excellent concise summary of the nineteenth-century welcome and then enmity for Chinese, and the passage of Chinese exclusion laws, in Bill Ong Hing, Making and Remaking Asian America through Immigration Policy, 1850-1990 (Stantord, Calif., 1993). 20-26. On Chinese exclusion, see also Hutchinson, Legislative History, 67-84, 104, 130, 431--33: and Sidney Kansas, U.S. Immigration: Exclusion and Deportation, and Citizenship of the United States of America, $2 \mathrm{~d}$ edn. (Albany, N.Y., 1940), 4-6, 303. The first restrictive immigration law, in 1875, prohibiting the entry of prostitutes and contract laborers, was aimed at Chinese in both categories. See Hing, 23; and Sucheng Chin, "The Exclusion of Chinese Women, 1870-1943," in Chan, ed, Entry Denied: Exclusion and the Chinese Community in America 1882-1943 (Philadelphia, 1991), 105-09.

${ }_{55}$ Hing, Making and Remaking, 48: Megumi Dick Osumi, "Asians and California's Anti-Miscegenation Laws," in Nobuya Tsuchida, ed. Asian and Pacific American Experiences: Women's Perspectives (Minneapolis, Minn., 1982), 8 . 
the Chinese Exclusion Acts were formulated and strengthened. Some federal judges, such as Edward Billings of Louisiana, concluded that the act of 1855 was purposely specific, "not intended as a general enactment upon the consequences of marriage between people of different nationalities." But many others presumed the opposite, including Henry Billings Brown in the eastern district of Michigan (soon to be appointed to the U.S. Supreme Court). Judge Brown noted with satisfaction that "legislation upon the subject of naturalization is constantly advancing towards the idea that the husband, as the head of the family, is to be considered its political representative, at least for the purposes of citizenship, and that the wife and minor children owe their allegiance to the same sovereign power." He found it appropriate "to apply the same rule of decision to a case where a female American citizen marries an alien husband, that we should to a case where an alien woman marries an American citizen." 56

The Expatriation Act of 1868, establishing for the first time that an American national could disavow citizenship, and detailing how, facilitated courts moving in Judge Brown's direction. Formalization of the option of expatriation ended the common-law tradition of indelible nationality. Great Britain did the same with its Naturalisation Act of 1870, which, in addition, specifically indicated that "a married woman shall be deemed to be a subject of the State of which her husband is for the time being a subject." By that point, European countries had more or less converged on the principle that a woman's nationality derived from her husband's. Nations in the Western political tradition translated modern respect for the elective quality of national allegiance to mean that, in the case of women, a choice in marriage expressed a decision about national belonging. ${ }^{57}$ If not a foregone conclusion, loss of American citizenship was certainly a risk for any American

5n Billings quotation, Comitis v. Parkerson et al., 56 Fed. 556 (C.Ct., E.D. Louisiana, 1893), at 562; Brown quotation, Pequignot v. Detroit, 116 Fed. 211 (1883), at 216, 214. Brown ascended to the Supreme Court in 1891 and served until 1906. Edwin M. Borchard, in "The Citizenship of Native-Born American Women Who Married Foreigners before March 2, 1907 and Acquired a Foreign Domicile," American Journal of International Law 29 (1935): 417, declared the Pequignot decision clearly wrong, dictated by public policy considerations rather than an accurate reading of the (common) law. On the indeterminacy on the question whether an American woman who married a foreigner lost her citizenship in the years 1855-1907, see Luella Gettys, The Law of Citizenship in the United States (Chicago, 1934), 113-19; Van Dyne, Citizenship, 127-41; Ernest J. Hover, "Citizenship of Women in the United States," American Journal of International Law 26 (1932): 703-04; Waltz, Nationality of Married Women, 25-33; Sapiro, "Women, Citizenship and Nationality," 7-8; Bredbenner, "Toward Independent Citizenship," 55-70. During this period, domicile often counted heavily, judges allowing wives who remained on American soil to keep their citizenship but depriving those who lived outside the country.

57 Waltz, Nationality of Married Women, 25; Richard W. Flournoy, Jr. [Assistant Solicitor, Department of State], "Naturalization and Expatriation," Yale Law Journal 31 (May 1922): 714; Van Dyne, Citizenship, 139-40; Dummett and Nicol, Subjects, Citizens, 87-90. Presumably influenced by the international trend, Justice Stephen Field peremptorily noted in a circuit court decision in California in 1887 that "a wife is by law a citizen of her husband's country" (although there was no such U.S. law); In re Langtry, 31 Fed. 879 (D. California, 1887), at 880. In Britain, a parliamentary report of 1923, entertaining the proposal to reverse the 1870 policy, gave a terse summary of the conservative position: "The Committee ... recognise the growing demand of many women and of organised women's societies for equal rights with men in every respect, but they cannot overlook the fact that by marriage a woman is merged in the unit of the family, and that within the family it is at present the husband who is head, who bears its legal responsibilities such as the maintenance of the wife, the children and the home, and whose occupation in most cases is the decisive factor as to where that home is to be established, and who among other things gives his nationality to the children. It is their opinion therefore that in this important sphere of family life the nationality of the husband should be the governing factor and 
woman who married a foreigner in the late nineteenth century. This was grievous enough for women who married foreign whites or Africans, whose husbands had the option of naturalization, but more dangerous for the citizen marrying an Asian man.

IN 1907, CONGRESS ENDED INDETERMINACY ON THIS QUESTION by expressly declaring "that any American woman who marries a foreigner shall take the nationality of her husband." Where in 1855 Congress had invited American men to absorb the national identity of the women of other groups, in 1907-the very height of immigration, when about a million immigrants were entering the United States each year-Congress told American women that marrying outsiders made them aliens in their own country. The 1907 law discouraged American women from marrying immigrants and prevented the wife in an immigrant couple from being naturalized on her own. By punishing American women who introduced foreign elements into the body politic, the act was akin to state laws that criminalized or nullified marriages between whites and people of color. The anti-Asian discrimination built into the 1907 law by naturalization policy echoed the spirit of laws passed between 1861 and 1913 in Arizona, California, Idaho, Montana, Nebraska, Nevada, Utah, and Wyoming that made marriages between Chinese and whites criminal and void. ${ }^{58}$

Alienage, placing the woman who married a foreign national outside the American political community, entailed more than a symbolic punishment. Common-law restrictions on the ability of aliens to hold real property had been eliminated in most states by the early twentieth century, yet several states passed new laws depriving "aliens ineligible for citizenship" (that is, Asians) of real property rights. The kind of political welcome given to (white male) aliens in the mid-nineteenth century had also dissipated. Only a few states still allowed alien declarants to vote. As the enfranchisement of women seemed increasingly possible, a woman's loss of citizenship by marriage might cost her political participation. Aliens suffered material restrictions, especially in occupational choice and public employment, and in the tightening of immigration law they increasingly faced deportation for various legal infractions. ${ }^{59}$

determine the nationality of the wife. If two ride a horse one must ride in front." Report by the Select Committee ... on the Nationality of Married Women (London, 1923), x-xix (quotation on xvi).

58 Congressional Record 41, 59th Cong. $2 \mathrm{~d}$ sess. (January 21, 1907), 1463-67; (February 27, 1907), 4116; (February 28, 1907), 4263-64; Bredbenner, "Toward Independent Citizenship," 35-36, 61-70, 93; J. Scott, et al., Citizenship of the United States, Expatriation, and Protection, 2-3, 33: Smith, Civic Ideals, 456-59; Flournoy, "Naturalization," 708-19. On state laws banning marriage across the color line, see the convenient summary in Fowler, Northem Attitudes, appendix. The act of 1907 did not nullify or criminalize any marriage as the state laws did, of course, but imposed a disincentive.

${ }_{59}$ By 1914, aliens could vote in only seven states and by 1921 , in only two. Kohler. "Legal Disabilities of Aliens"; Aylsworth, "Passing of Alien Suffrage." Four western states enfranchised women by 1896 , and then none until 1910 to 1912, a breakthrough period when California. Washington, Oregon, Kansas, and Arizona gave women the vote. Women could vote for president in twenty-eight states before the nation ratified the Nineteenth Amendment in 1920. See the convenient summary in Anne F. Scott and Andrew Scott, One Half the Prople: The Fight for Woman Suffrage (l'hiladelphia, 1975), $166-68$. 
Congress passed this 1907 provision with very little discussion, as part of a larger effort to streamline and rationalize immigration policy and bring it thoroughly under federal control. Congress found it easy to translate the old legal fiction of marital unity into the doctrine of "family unity" in citizenship. Announcing a continuing commitment to the primacy of male citizenship and headship of the family, the provision seemed a political anachronism amid the vast scene of women's public activism that had materialized by 1907 . It reiterated that a wife owed her primary political allegiance to her husband rather than to her nation. ${ }^{60}$ Proponents of the provision erroneously said that it was merely "declaratory," meaning that it codified the existing state of the law. They ignored whether or not the United States could implement the law fully, which it could not, without having the power to award another nation's citizenship. If the husband's country did not adopt wives of their male citizens (and not every country did), then the formerly American wife became a woman without a country.(1)

As of 1907, then, public policy treatment of male citizens who married foreigners contrasted starkly with treatment of female citizens who did the same. The American man's wife and children were welcomed into political belonging unless the racial limitation was overstepped, but the American woman and her foreign husband were ejected from the national community. Although the economic basis for regarding would-be husbands as independent full citizens and would-be wives as dependents had been mitigated by women's employment, the institution of marriage still weighed on citizenship with tremendous inertia. The peculiar impact of marriage on a wife's nationality appears in the donning and doffing of citizenships consequent upon widowhood or divorce. A foreign-born woman who gained citizenship by marriage to an American was presumed to retain it after his death. Yet an American woman who lost her citizenship by marrying an alien could

60 The same act took away the citizenship of a naturalized American who returned to his or her native country for two years or resided in another foreign country for five years, and required that the minor child of a naturalized American father establish U.S. residence before being granted citizenship. See J. Scott, et al., Citizenship of the United States, Expatriation, and Protection (this report recommended the 1907 change); Bredbenner, "Toward Independent Citizenship," 61-66. Sophonisba P. Breckinridge called the policy of the male head's citizenship determining that of his wife and children the "family unity" doctrine, in Marriage and the Civic Rights of Women (Chicago, 1931), 50-55; so did Waltz, Nationality of Married Women, 44-48, and both considered it patriarchal. The move from coverture to "family unity" might be seen as a status modernization in Reva B. Siegel's terms, as argued in "Modernization of Marital Status Law"; and "The Rule of Love': Wife Beating as Prerogative and Privacy," Yale Law Journal 105 (June 1996): 2117-2220.

${ }^{61}$ Congressional Record 41, 59th Cong., 2d sess. (January 21, 1907), 1463-67; (February 27, 1907), 4116; (February 28, 1907), 4263-64. No congressman was sufficiently well informed or bold enough to object that case law did not unequivocally establish that a woman's nationality followed her husband's. In an earlier discussion of a bill to allow the American widow or divorced wife of a foreigner to regain her citizenship (a bill that did not pass), senators also assumed that any married woman's nationality was the same as her husband's. Congressional Record 39, 58th Cong., 3d sess. (January 14, 1905), 829-31. Borchard points out, "Citizenship of Native-Born American Women," 409, that several lower courts in the United States were wrong in saying that the act of March 2,1907, made declaratory what had been a common-law rule, that a married woman's citizenship followed her husband's. SecklerHudson, Statelessness, 33-37. Because the first civil code in the Soviet Union, for instance, said that marriage between a Russian national and a foreigner did not automatically change citizenship for either one, an American woman marrying a Sovict citizen would be stateless unless she took affirmative action to adopt Soviet citizenship. This happened to the dancer Isadora Duncan, who married a Russian and wished to remain an American, not to become a Soviet citizen, but the U.S. government no longer regarded her as a citizen. 
resume it upon divorce or widowhood as though it had simply been suspended for the duration of her marriage. The act of 1907 codified the point that if she did, her minor children born abroad would become citizens upon taking up residence in the United States. ${ }^{62}$ Two opposite principles are visible here on the permanence of the citizenship change effected by marriage. They converged, arguably, in an unarticulated national aim to enable American mothers to stay within the polity, which again captured women's political character within a familial if not strictly marital dependence.

The woman suffrage movement at the time was moving in the opposite direction, presenting its case for women as political individuals. When the constitutionality of the 1907 act was decided by the Supreme Court, women could vote in a dozen states. Ethel Mackenzic had been prevented from registering to vote in California on the grounds that she had lost her citizenship by marrying an Englishman. She fought this, contending that it was unconstitutional for Congress to take away a citizen's birthright. Both the California high court and the Supreme Court were unsympathetic to her view. Bypassing the precedent of Shanks is. Dupont, and embracing the "ancient principle" of "the identity of husband and wife," Justice Joseph McKenna noted the importance of the Expatriation Act and concluded that Ethel Mackenzie's marriage to a foreigner must be judged "as voluntary and distinctive as expatriation." 6.3

By going to court, Mackenzie created a good deal more legal commentary and public objection about the policy regarding married women's nationality than the passage of the act of 1907 had. Public awareness was further stimulated during World War I by the complaints of a number of American-born women married to German immigrants, who were declared "enemy aliens" and had their property seized by the Alien Property Custodian. ${ }^{64}$ Leaders of the woman suffrage movement-more than a few of whom had married Europeans-rejected the notion that marriage should decide a woman's political allegiance. Many suffragists were appalled that an American woman could be expatriated by marriage and also

n2 See Van Dyne, Citizenship, 134-42.

6.3 Mackenzie v. Hare, 239 U.S. 299 (1915), 311, 312. McKenna's contention that "the identity of husband and wife ... has purpose, if not necessity, in purely domestic policy; [but] it has greater purpose and, it may be, necessity, in international policy," ignored Story's view in Shanks v. Dupont, 3 Pet. 242 (1830), 248. In U.S. v. Wong Kim Ark, 165 U.S. 649 (1898), 703, Justice (3rav's opinion had said, "The power of naturalization, vested in Congress by the constitution, is a power to confer citizenship, not a power to take it away," but the California supreme court saw this as no bar to refusing Ethel Mackenzie's claim, because "the court in the quoted sentence was speaking of the power of Congress to deprive a person of his citizenship without his consent and for no sufficient or reasonable cause," whereas Mackenzie had consented to marriage and it was reasonable for Congress to require that a wife's citizenship be the same as her husband's. Mackenzie v. Hare. 165 Cal. 775 (1913), 785, 783. Smith, Civic ldeals, $456-59,632-33 \mathrm{nn}$. 154-58, puts Mackenzie in a line of conservative, protectionist Supreme Court decisions regarding women's maritalicivic status in the Progressive Era.

o4 Waltz, Nationality of Married Women, 12-13, 14; Bredbenner, "Toward Independent Citizenship," 67-68, 117-18; Jorg Nagler, "Victims of the Home Front: Enemy Aliens in the United States during the First World War," in Minorities in Wartime: National and Racial Groupings in Europe. North America and Australia during the Two World Wars. Panilos Panayi, ed. (Oxford, 1992), 191 215; Gettys, Law of Citizenship, 139-40; Cyril D. Hill, "Citizenship of Married Women." American Joumal of International Law 18 (1929): 724-25. "So startling." notes Hill, were the situations of some Anterican-born women married to Germans, whose property had been seized by the Alien Property Custodian, that congressional action was deemed necessary, and an act was passed in 1921 releasing property of "American-born women whose status was technically that of alien enemies by reason of marriage." 
disapproved of the gift of citizenship to a foreigner who became an American's wife. New York suffragists added to that state's 1917 referendum, which gained them the vote, a stipulation that the citizenship granted to a foreign-born wife of an American citizen would not enable her to vote unless she had been resident for five years, which was the standard residency requirement for naturalization. ${ }^{65}$

After the passage of the Nineteenth Amendment, organized women moved quickly and almost unanimously to challenge the provisions of 1855 and of 1907 , to eliminate consequences of marriage for women's citizenship. This was so clearly seen as a goal of women that both major parties included platform planks on it in the presidential campaign of 1920. The initial result was the Cable Act of 1922 , named for its congressional sponsor John Cable, Republican of Ohio. Women lawyers had put the issue of wives' nationality into congressional hearings in the $1910 \mathrm{~s}$, but the enfranchisement of women made all the difference. As soon as women got the ballot, a Massachusetts representative remarked during floor debate, the existing relation between marriage and citizenship became "as archaic as the doctrine of ordeal by fire." 60

The mediating role of husbands' nationality should have been eliminated entirely once women were admitted to the sovereign power of the people, but it was not. The Cable Act asserted the principle of "independent citizenship" for married women without implementing it fully. While overruling the 1907 declaration and enabling the American wife of a foreigner to retain her citizenship, the Cable Act specified that if she lived for two years in her husband's country or five years in any foreign nation, she was deemed to have given up her American nationality, as any naturalized citizen in that situation would be. ${ }^{67}$ The act thus kept in place sharp distinctions between husbands and wives. Congress did not allow the American woman who married a foreigner to retain her citizenship absolutely, because it remained dependent on her residence, which was tied to her husband's domicile. Marriage was still seen as undermining a woman's, and not a man's, political

${ }^{65}$ See Mary Sumner Boyd, "Have You Been Enfranchised Lately?" Woman Citizen (January 5 , 1918): 114 .

66 J. Stanley Lemons, The Woman Citizen: Social Feminism in the 1920s (Urbana, Ill., 1973), 63-68, 235-37, includes a brief and helpful overview of the Women's Joint Congressional Committee's movement to achieve "independent citizenship" and the Cable Act's provisions; Waltz, Nationality of Married Women, 14; Crozier, "Changing Basis," 132-33. In the House of Representatives' discussion of the bill, members frequently referred to the party platform planks. See Congressional Record 62, 67th Cong., 2d sess., 9039-67; quotation from John Rogers on June 20, 1922, 9047. Rep. Siegel of New York similarly interpreted the impact of woman suffrage, saying, "As to the right of the woman to be an independent American citizen in her own right there can be no controversy, because the nineteenth amendment to the Constitution has settled that for all time" (June 20, 1992). Debate on the Cable Act took place in the House with from 83 to 105 members present, less than a quorum. On efforts in the 1910s, see Bredbenner, "Toward Independent Citizenship," 96-97; and "American Citizenship Rights of Women," Hearing before a Subcommittee of the Committee on Immigration, United States Senate, 72d Cong., 2d sess., March 2, 1933.

67 The act was written in these peculiar terms: "the right of any woman to become a naturalized citizen of the United States shall not be denied or abridged because of her sex or because she is a married woman." Bredbenner, "Toward Independent Citizenship," 157-58, stresses that the State Department's reluctance to protect compromised American citizens abroad was reflected both in the passage of the 1907 act and the grudging grant of only naturalized citizenship in the Cable Act; also see Seckler-Hudson, Statelessness, 42-44. 
allegiance. Furthermore, the new law incorporated the racial prejudice of naturalization policy. Any American woman who married someone "ineligible for citizenship" by naturalization (that is, mostly Asians, although also anarchists and polygamists) lost her citizenship as before under the act of 1907 .

The Cable Act also eliminated the American male's power and privilege to endow his foreign-born wife with citizenship simply by marrying her. Instead, these wives were given a streamlined naturalization opportunity: they would have to wait only a year rather than the standard five years, and they could bypass the stage of declaring intent, but they did have to go through the procedures. Congressmen justified the change by claiming it would provide an educational stimulus: foreignborn wives would no longer be passive recipients of citizenship but "equal partners" with their husband-citizens, better able to rear American children. An American man's right to create a fully American family held a strong place in the hearts of congressmen, but the Nineteenth Amendment had aroused a counter-prejudice against foreign-born women becoming voters immediately upon marrying American men. The lug-of-war between these two prejudices resulted in the bargain that foreign-born wives of American citizens were no longer incorporated automatically but had to be resident one year and pass through naturalization in order to become citizens. ${ }^{69}$ Congress did not even consider clearing a path to nituralization for American women's foreign-born husbands.

If the Cable Act meant to enshrine the principle of independent citizenship, why these complications? Why did it not simply emancipate citizenship from marriage considerations completely? The limitations in the law recorded congressmen's attachments to the prerogatives of male citizens and the contemporary public hostility toward immigrants, especially those seen as racially unassimilable. After the Chinese exclusion laws, immigration had been further regulated and limited by Congress in 1891, 1903, 1907, and 1910. In 1917, exclusion was extended to virtually all of Asia. At its height in the early 1920s when the Cable Act was passed, the restriction movement was fueled by anxiety on the part of white Americans that the "true" American type was being overrun and outmanned, that American standards

68 All treatments of the Cable Act note this discrimination, including Lemons. Woman Citizen, 67; Breckinridge, Marriage, 23-25; Bredbenner, "Toward Independent Citizenship," 151-55; Hill, "Citizenship of Married Women," 727. Waltz, Nationality of Married Women, 43 44. Gettys, Law of Citizenship, 124-25, points out that the clause punishing women who married "ineligible aliens" actually contravened the act's first section, which declared "that the right of any woman to become a naturalized citizen of the United States shall not be denied or abridged because of her sex or because she is a married woman." Text of the Cable Act is reproduced in "American (itizenship Rights of Women," 44. Under this act, an American woman who lost her citizenship by marriage no longer automatically regained it if the marriage ended (as under the 1907 statute), but she had to wait a year and undergo naturalization procedures to regain it. In another instance of sex discrimination, the act described how an American woman might voluntarily renounce her citizenship upon marriage to a foreigner, before any court with jurisdiction over naturalization, but did not suggest that a man marrying a foreigner might do the same; Waltz, Nationality of Married Women, 4t. For a conservative critique of the Cable Act, see Richard W. Flournoy. Jr., "The New Married Women's Citizenship Law," Yale Law Journal 333 (December 1923): 159-70.

Congressional Record 92, 67th Cong., 2d sess., 9039-67. Sapiro, "Women, Citizenship and Nationality," esp. 13-16, contends that passage of the Cable Act depended on congressmen's wish to institute more rigorous naturalization procedures for alien wives of American citizens, in order to restrict the immigrant vote. On political efforts surrounding passage, see Bredbenner. "Toward Independent Citizenship," 119-35; she records how earlier, less freighted versions of an independent citizenship bill did not progress. 
of life and work were being undercut by swarthy and non-Protestant hordes from the Mediterranean, Eastern Europe, Russia, and parts of the world even less known or trusted. The 1921 Quota Act and the culminating 1924 Immigration Act drastically lowered the ceiling for all newcomers and established maximum quotas for groups by national origin, mimicking the ethnic makeup of the United States before the great waves of immigration from 1880 to 1920 . The 1924 act barred foreigners who could not be naturalized from even entering the country. All Asians, not just Chinese laborers, were inadmissable, as well as ineligible for citizenship. ${ }^{70}$

The Cable Act in conjunction with immigration restriction created cases such as that of Ng Fung Sing. The American-born daughter of Chinese parents and thus an American citizen, she returned to China for a number of years and married a Chinese husband in 1924. Not long afterward, her husband died. As a widow, she traveled back to the United States to resume her privileges as a citizen, but immigration authorities refused her admission when she arrived in Seattle. In the eyes of American law, her marriage made her a Chinese subject, inadmissible into the country. The Immigration Act of 1924 additionally provided that "an immigrant born in the U.S. who has lost his U.S. citizenship shall be considered as having been born in the country of which he is a citizen or subject." Such provisions seemed expressly designed to keep a woman of Asian descent like $\mathrm{Ng}$ Fung Sing from her American birthright. A federal court confirmed the immigration officials' judgment. Even if $\mathrm{Ng}$ Fung Sing had married an Asian national in the United States, she would have been in the same situation. An American-born woman who had lost her citizenship by marriage could resume it by abbreviated naturalization procedures if widowed, but $\mathrm{Ng}$ Fung Sing did not meet the racial requirement for naturalization. The racial discrimination in the Cable Act had a particular impact on the Asian-American population. Those born in the United States gained citizenship, under the Fourteenth Amendment. If, however, an American-born woman of Asian descent was courted by a resident Asian national (a highly likely scenario because of the skewed sex ratio-older Asian men had to look to the younger generation for wives), she would have to sacrifice her American citizenship permanently to marry him. ${ }^{71}$

${ }^{70}$ On the making of the 1924 law, see Hutchinson, Legislative History, 484-85. The history of immigration restriction to 1924 has been detailed by many historians; see, besides Hutchinson, Legislative History; Kansas, U.S. Immigration; John Higham, Strangers in the Land: Patterns of American Nativism, 1860-1925, corrected edn. (New York, 1963); Michael C. LeMay, From Open Door to Dutch Door: An Analysis of U.S. Immigration Policy since 1820 (New York, 1987).

${ }^{71}$ Ex parte Fung Sing, 6 F. 2d 670 (1925); Waltz, Nationality of Married Women, 46. Bredbenner, "Toward Independent Citizenship," offers detailed and worthwhile examination of the conflicts between "family unity" and immigration restriction in the 1920 s. For examples where married women became stateless because of the racial limitation of the Cable Act, see Seckler-Hudson, Statelessness, 40, 61. In U.S. v. Wong Kim Ark, 165 U.S. 649 (1898), a divided Supreme Court affirmed that the child born of Chinese parents on American soil was an American citizen. See Chan, "Exclusion of Chinese Women," 128-29; and Osumi, "Asians and California," 15-16, for the impact of the Cable Act's racial limitation on Asian-American communities. Osumi claims that the "aim [of this clause] was to discourage Nissei [second-generation Japanese immigrant] women and women of other races from marrying Issei [immigrant-generation] men." It is probably more accurate to say that this was a result, rather than an aim, for there is no direct evidence that this was intended. Osumi points out that, in 1920, 42 percent or more of the Japanese men over fifteen were unmarried. According to Hing, Making and Remaking, 55, the sex ratio among the Japanese population in the United States at that time was almost 2 to 1 (down from 7 to 1 in 1910 because the so-called Gentlemen's Agreement [1907] allowed 
Mary K. Das, a white American of almost-Mayflower lineage, was also deprived of her national identity because of the Cable Act and the racial restriction on naturalization. She thought she married an American citizen when she married a native of India who had been naturalized. That was in 1914, during a period when a number of Asian Indians managed to proceed through naturalization on the reasoning that they were ethnologically classified as Aryan or Caucasian and therefore fit the requirement of "free white persons." But in 1923, the Supreme Court put aside the Caucasian classification and decided that people from the Indian subcontinent were not "white" as the word was commonly understood in 1790. The court interpreted the 1790 statute as intending "to confer the privilege of citizenship upon that class of persons whom the fathers knew as white" and to deny it to others. ${ }^{72}$ Retroactive application of this doctrine deprived Taraknath Das of his citizenship-which for ten years prior he had believed valid-and, because of the discrimination in the Cable Act, stripped his wife of hers. When Mary K. Das applied for a passport, she was refused. She became an activist on the issue, enlisting members of the National Woman's Party in her cause. Lobbying Congress for amendments to the Cable Act, she reported bitterly that "some Representatives and Senators, members of the Immigration Committees of the two houses of Congress, hold that the ideal of Americanism should keep any American woman from marrying any foreigner, particularly an Asiatic."73

During the House debate on the Cable bill, a couple of representatives had noted the sex discrimination involved in punishing an American woman but not an American man for marriage to an Asian. The best response that a strong proponent of the bill, John Raker of California, could muster was, "The man has always had

wives and children of Japanese men already in the country to enter); the sex ratio among the Chinese population was nearly 7 to 1 , down from 14 to 1 in 1910 (presumably by natural increase).

72 U.S. v. Bhagat Singh Thind, 361 U.S. 204 (1923), 208, quoting a decision of the prior year, Takao Ozawa v. U.S., 260 U.S. 178 (1922), which declared Japanese also ineligible. See Ian Haney-Lopez, White by Law (New York, 1996), 79-102, on the "common knowledge" definition of whiteness in Thind. According to Joan M. Jensen, Passage from India: Asian Indian Immigrants in North America (New Haven, Conn., 1988), 255-56. at least sixty-nine Indians had been admitted to American citizenship between 1908 and 1922.

${ }_{73}$ Taraknath Das was not a run-of-the-mill Indian immigrant: he had been a prominent, radical leader in the Indian nationalist movement in North America since his arrival in 1906, frequently under surveillance from the Canadian and American authorities acting in the interests of Great Britain and briefly imprisoned in San Francisco in 1919 for Home Rule activities. After several years of trying, Das gained U.S. citizenship in California in 1914. The U.S. authorities specifically sought to denaturalize him after the Thind decision. More than sixty Indians were deprived of naturalized U.S. citizenship in the mid-1920s in consequence of Thind, and forty-five more cases were pending when the Justice Department--stymied by Supreme Court inaction on the case of S. G. Pandit. a radical lawyerdropped the effort. Jensen, Passage from India, 165-74, 184-85, 232-53, 260-63.

Both Mary and Taraknath Das were stateless as a consequence of denaturalization: while American authorities claimed that Indians who were deprived of their American citizenship reverted to their former status as British subjects, in fact British law stipulated that any subject who had voluntarily been naturalized in another country lost British nationality. Mary and Taraknath Das married in 1924, after the decision in U.S. v. Thind. She had consulted lawyers as to whether she migh। lose her citizenship by the marriage and was assured by "experts," including a former adviser to the State Department, that a Supreme Court decision would never have retroactive effect. Mary K. Das, "A Woman without a Country," Nation 123, no. 3187 (August 4, 1926): 115-06: Emma Wold, "A Woman Bereft of Country," Equal Rights. August 15, 1925; Cohen, "Legal History." 42-52; Bredbenner, "Toward Independent Citizenship," 289-91. The justification for revocations of previously granted citizenships following Thind was that the naturalizations had been illegal and void: see Seckler-Hudson, Statelessness, 164-73. 
his right of citizenship. The men have dominated the thing from the beginning." When a Kentucky representative tried to make the racial discrimination evenhanded, his proposal to take citizenship away from American men who married "ineligible" aliens was quickly rejected. To serve the goal of racial homogeneity, Congress had no trouble reading American women out of the polity for straying but balked at restricting the freedom of American men to select wives. ${ }^{74}$

So important in national thinking and in immigration policy was the principle that American male citizens ought to be able to create and sustain their chosen families that it sometimes triumphed over the racialized nationalism of the period. The restrictive act of 1924 created a class of "nonquota" immigrants to satisfy that principle. During the few years that the Quota Act of 1921 was in force, an American man who found a bride in a foreign country could bring her home only if she fit under the quota of her country of origin. This affront to the male citizen's right to create and unify a family caused so much furor and disbelief that the 1924 law established a nonquota admissible category of the wives and children of American male citizens. Women citizens with foreign husbands were not similarly favored, and Congress responded slowly and hesitantly to women's lobbying on this issue. In 1928, a revision allowed nonquota status to husbands of American citizens married up to that year. Four years later, heeding some congressmen's fears that American women abroad were being fooled into marriage by foreigners who only wanted admission to the United States, Congress refused to embrace an openended commitment to American women's foreign husbands, allowing nonquota status to those who had married by 1932 only. ${ }^{75}$

\footnotetext{
${ }^{74}$ Congressional Record 62, pt. 9, 67th Cong., 2d sess., June 20, 1922, 9057, 9063-64. Just at this time, ironically, the Supreme Court first articulated (in dicta) the right of the individual "to marry, establish a home and bring up children" as a Fourteenth Amendment liberty. Meyer v. Nebraska, 262 U.S. 390 (1923). The "freedom to marry" was not established doctrinally until Loving v. Virginia, 388 U.S. 1 (1967).

${ }^{75}$ The first Quota Act (1921) gave family members of male citizens first preference under the quota, above the husbands of American citizens and above American women who had lost their citizenship through marriage and wanted to return to become naturalized. American women who had lost their citizenship by marriage between 1907 and 1922 were not admitted outside the quota (by the 1921 or the 1924 act): they had to re-enter the country as quota immigrants, in order to move toward regaining their citizenship through naturalization! Waltz, Nationality of Married Women, 47; Marjorie P. Hoinko, "Naturalizing a Yankee," Woman Citizen (April 13, 1928): 38-39; Bredbenner, "Toward Independent Citizenship," $151-55,203-06,221-22,235-40$. On establishing nonquota status for American citizens" foreign husbands, see Congressional Record, 72d Cong., 1st sess., 8406-09 (April 18, 1932), 14588-89 (July 5, 1932), 14694-95 (July 6, 1932); and H.R. Reports No. 919, March 26, 1932; and No. 1753 (July 5, 1932), House Reports on Public Bills, etc., 72d Cong., 1st sess.

Asian-American men did not receive the usual prerogatives of male citizens and husbands. The immigration act of 1924 prohibited admission of persons ineligible to citizenship, while making special provisions for nonquota entry of citizens' wives; and, if someone was both, the racial limits on admissibility governed, the Supreme Court said in a 1925 case concerning Chinese women married to American citizens (of Chinese ancestry). The men in this case, though American citizens, could not have their wives join them. Chinese-American men lobbied the congressional immigration committees for years for an amendment to the Cable Act: in 1930, Chinese wives of American citizens who had married before 1924 (not all Chinese wives) were given a special dispensation to enter the country. Chang Chan et al. v. Nagle, 268 U.S. 346 (1925); Valeska Bari, "Citizens Who May Not Have Wives," Woman Citizen (December 1927): 20-21; Breckinridge, Marriage, 31-32; Chan, "Exclusion," 125-26; Bredbenner, "Toward Independent Citizenship," 247-52, 256-57.
} 
THESE SEX AND RACE DISCRIMINATIONS sparked insistent pressures for reform from organized women and from Chinese Americans. As a result, Congress amended the Cable Act in 1930, 1931, and 1934, until the discriminatory consequences of marrying an "alien ineligible for citizenship" were eliminated and women's citizenship fully separated from marriage consequences. By 1934, American women were relieved of a citizenship detriment from marriage; Americans of both sexes gained the same naturalization benefits for their foreign-born spouses, and mothers the same right as fathers to convey citizenship to their children born abroad. ${ }^{76}$ Not until 1947, however, following the wartime alliance between the United States and China, consequent repeal of the Chinese Exclusion Acts, and the postwar occupation of Japan, were all racial barricrs excluding citizens' spouses from entering the country lifted. During the Cold War, the United States presented itself to non-aligned nations of colored peoples as the leader of the "free world." Five years later, the McCarran-Walter Act eliminated overt racial bars to citizenship, although the quotas for Asian admission were still so small that exclusion was only nominally ended. ${ }^{77}$

The National Woman's Party, the former "militant" suffragists advocating an Equal Rights Amendment to the Constitution, had led in the reforms of the Cable Act. They persuaded James Brown Scott, principal author of the report leading to the 1907 act and a leader in international law circles, to change his mind and become their ally by $1930 .^{78}$ At that point, U.S. representatives began to stand

76 The amendments of 1934 made the latter two changes. The residence time required for citizenship for the foreign-born spouse of an American citizen was lengthened from one 10 three years when husbands were included. On the 1931s amendments, see Waltz, Nationality of Married Women, 51-58, Breckinridge, Marriage, 39-40; Hover, "Citizenship of Women in the United States," 718-19; Crozier, "Changing Basis"; Bredbenner, "Toward Independent Citizenship," 339-40, 473-79; Cohen, "Legal History," 42-52. Text and discussion of the 1930 and 1931 changes are conveniently assembled in "American Citizenship Rights of Women." those of 1934 in H.R. Report No. 1.31 [from the Committee on Immigration and Naturalization], House Reports on Public Bills .... vol. 1, 73d Cong., 1st sess. The most extensive debate on the 1934 change, called "The Equal Nationality Bill" by its proponents, is in Congressional Record, 73d Cong., 2d sess., pt. 7. 7329-59 (April 25, 1934). The policies that denationalized Ng Fung Sing and Mary K. Das were undone by the act of March 3, 1931: it provided that an American citizen by birth who had lost her citizenship by marrying, before March 3, 1931, an ineligible alien, would not be denied naturalization on account of race; if her marrage took place after that date, she retained her American citizenship.

77 Cohen, "Legal History," 42-52; and see Robert A. Divine, American Immigration Policy, 1924-1952 (New Haven, Conn., 1957).

${ }_{78}$ Note that the NWP's earliest wording for the Equal Rights Amendment was, "Equal rights with men shall not be denied to women or abridged on account of sex or marriage" (emphasis added); quoted in Nancy F. Cott, The Grounding of Modem Feminism (New Haven, Conn., 1987), 325 n. 13. In its "equal nationality" effort. the NWP took a gender-based position, seeking a result that was also anti-racist. On the NWP and League of Women Voters on this issue, see Susan D. Becker, The Origins of the Equal Rights Amendment: American Feminism between the Wars (Westpori, Conn., 1981), esp. 161-95; Bredbenner, "Toward Independent Citizenship," 292-99, 339-40, 386-500; Emma Wold, "Hearings on Married Women's Citizenship." Equal Rights [the journal of the NWP] (April 3, 1926): 63-64; Burnita Shelton Matthews, "Woman, Wedlock and Nationality," ibid.. 21: Emma Wold, "The Ins and Outs of a Woman's Citizenship," Fqual Rights (February 8, 1930): 3-4. The women's movement for equal nationality was international by 1920; see Waltz, Nationality of Married Women, 120; Leila J. Rupp, "Construeting Internationalism: The Case of Transnational Women's Organizations, 18881945," AHR 99 (December 1994): 1571-1600; Dorothy P. Page, "AA Married Woman, or a Minor. Lunatic or Idiot': The Struggle of British Women against Disability in Nationality, 1914-1933" (PhD dissertation, University of Otago, Dunedin. New Zealand, 1994). See also J. W. Garner, "Uniformity of Law in Respect to Nationality," American Journal of International Law 19 (1925): 547-53; Chrystal MacMillan, "Nationality of Women: Present Tendencies," Journal of Comparutive Legislation and 
firmly against sex discrimination in nationality. International law conflicts on the issue sometimes resulted in statelessness, which had become a worrisome general concern in the 1920 s because of the migrations and redrawing of national boundaries that followed World War I. If a woman from a nation whose law said she took her husband's citizenship married a man whose country did not assume her allegiance, she became stateless. After 1922, most European women who married Americans would face this situation. The foreign wife of an American citizen could come into the United States as a nonquota immigrant, but she had to remain stateless for at least a year before being naturalized. In countries that did not welcome naturalization, stateless wives were in greater difficulty. Examples of very complicated and protracted citizenship problems caused by conflicts in laws regarding spouses were cited in abundance during the 1930s. U.S. representatives at the time advocated independent citizenship for married women as the best solution to international law conflicts. ${ }^{79}$

How did it happen that the United States renovated its longstanding discrimination between the nationality of husbands and wives, that advocates were able to move Congress in the early 1930s where it had not gone in 1922? Although the Nineteenth Amendment brought about the most definite rupture in the traditional policy, the equalization was not an automatic result of women's graduation to voting rights. The Cable Act revisions may have represented congressmen's appreciation for women voters, but this seems unlikely to be the major reason, since women's advocacy groups were not united in their approaches to revision, and, more generally, legislators seemed to have cared little about courting "the women's

International Law, 3d ser., 7, pt. 4 (1925); Gettys, Law of Citizenship, 137-39, 184-92; Seckler-Hudson, Statelessness, esp. 78-92; Waltz, Nationality of Married Women, 59-.79, 86-96; typescript by Maud Younger on 1934 nationality work, in Jane Norman Smith MSS, Box 11, folder 213, Schlesinger Library, Radcliffe College, Cambridge, Massachusetts.

The relationship between Doris Stevens, an NWP leader, and James Brown Scott seems to have been instrumental in the latter's reversal of his views on married women's nationality. Stevens's papers reveal a very effusive emotional attachment, perhaps a love affair, between her and Scott from 1929 to 1935 (both of them married to others at the time). Doris Stevens collections no. 76-246, folders 160-61; no. 78-M146, folder 13, Schlesinger Library. For his 1930-1931 views, see James Brown Scott [Secretary of the Carnegie Endowment for International Peace and Director of its Division of International Law; President of the American Institute of International Law; Chairman of the Standing Committee on International Law of the American Bar Association], Observations on Nationality with Especial Reference to the Hague Convention of April 12th, 1930 (New York, 1931); and "Nationality," editorial comment, American Journal of International Law 24 (July 1930): 1-6.

${ }^{79}$ The United States, adopting the NWP position, was one of the few countries declining to sign the convention on married women's citizenship status decided on at the 1930 Hague Conference on the Codification of International Law, because what it prescribed was not sufficiently equalitarian: the convention stipulated that a married woman should take her husband's nationality if his nation automatically awarded it to her or, if not, keep her own. A French reform of 1889 had revised the Code Napoleon to say that a French woman lost her nationality only if marrying a foreigner whose country automatically endowed the wife with new citizenship; in 1927, a further reform allowed a French woman to retain French citizenship if she married a forcigner (and generally facilitated naturalization); see Brubaker, Citizenship and Nationhood, 215 n. 177; Seckler-Hudson, Statelessness, 94-95, on France and more generally, for examples of married women's problems as a result of conflicts of laws. Germany followed the policy that the husband's citizenship was determinative and did not welcome naturalization; Brubaker, 114-15. In 1932, to address problems of statelessness, Britain revised its policy, depriving a woman marrying a foreigner of her citizenship only if the husband's nation automatically made her its citizen, in accordance with the 1930 Hague Convention; Waltz, Nationality of Married Women, 62. 
vote" as such after the mid-1920s. Perhaps the rising ideal of companionate marriage in social science and social work circles influenced Congress to reject the vestiges in nationality law of the patriarchal principle of family unity. ${ }^{80}$ Certainly, the likelihood that American women would be courted on their own home grounds by foreign-born suitors shrank as a result of the 1924 Immigration Act. As with Justice Story's reference to "the law of nations," echoed in the congressional actions of 1855 and 1907 , the international situation may have weighed most heavily in the balance: U.S. policy makers now aimed for world leadership rather than conformity to European practice, but national priorities still had international meanings. A fundamental characteristic of national citizenship, of course, is that it matters only amid a colloquy of nations. The United States came to stand for the "equal nationality" principle-to which several Latin American countries and the Soviet Union also adhered-as against benighted European practice. Internationally, this position prevented the United States from being upstaged by the Soviet Union on sex discrimination and underlined the nation's role as standard-bearer for democratic equal justice at a time of looming fascism.

Watershed that it was, the "Equal Nationality Bill" of 1934 (as the National Woman's Party liked to call it) cannot be said to have signaled the attainment of full citizenship for married women, hence for women in general. Despite the Nineteenth Amendment and women's access to political parties and office holding by 1934, a startlingly large number of states still fought equal admission or recruitment of women to juries, from the 1920 s to 1975. Jennifer K. Brown has found two alternative readings of the Nineteenth Amendment in court decisions on jury rights. Some judges took what Brown calls an "emancipatory" view of the Nineteenth Amendment's impact, assuming that women's admission to the vote ipso facto entitled them to full political participation. But others maintained an "incremental" approach, contending that the common-law tradition excluding women from juries could stand, because the ballot was a discrete right not inherently capable of transforming women's political character. This divided or doubled view of the meaning of enfranchisement suggests a much broader ambivalence about the citizenship to which women had warrant to aspire. For black women in the South, legal and customary bars to African-American political rights made even the

\footnotetext{
${ }^{80}$ On politicians' lack of interest in women voters, see Lemons, Woman Citizen; Estelle B. Freedman, "Separatism as Strategy: Female Institution Building and American Feminism, 1870-1930," Feminist Studies 5 (1979): 512-29; Sara Alpern and Dale Baum, "Female Ballots: The Impact of the Nineteenth Amendment," Journal of Interdisciplinany History 16 (1985): 43-67; Felice Gordon, After Winning: The Legacy of the New Jersey Suffragists, 1910-1947 (New Brunswick, N.J., 1986): Cott. Grounding, 243-83; Evelyn Brooks Higginbotham, "In Politics to Stay: Black Women Leaders and Party Politics in the 1920 s," in Tilly and Gurin, Women, Politics and Change, 199-220; Kristi Andersen, After Suffrage: Women in Partisan and Electoral Politics before the New Deal (Chicago, 1996); on companionate marriage, Christina Simmons, "Companionate Marriage and the Leshian Threat," Frontiers 4, no. 3 (1979): 54-54; Linda Gordon, Woman's Body, Woman's Right: A Social Histon of Birth Control in America (New York, 1976), 301-41): and compare Barbara Melosh, Engendering (ulture: Manhood and Womanhood in New Deal Public Art and Theatre (Washington, D.C., 1991 ).
} 
Nineteenth Amendment a hollow reality, as did limits in some western states on voting by people of Chinese descent, Latinas, and Indians. ${ }^{81}$

Yet women, married or single, had graduated to more than minimal citizenship. In some respects, the mid-1930s marked an unprecedented high point in the national imagination for the potential of women as citizens. The leadership exercised by Eleanor Roosevelt and Frances Perkins, along with other vocal and effective women in New Deal agencies and in the resoundingly successful Democratic Party, gave the impression that women had become integrated politically. The Pictorial Review in 1936 even proposed and discussed twelve women suitable to serve as president of the United States. 82 The gender differentiation in much New Deal legislation presented a striking ideological disparity, however, to evidence of women's becoming equal citizens. With the New Deal, the United States began to join other industrialized nations by placing social and economic welfare alongside political citizenship. The New Deal redefined the meaning of citizenship in the United States. Yet, with respect to gender, the redefinition was a throwback. When President Franklin D. Roosevelt asserted that government had an "inescapable obligation" to "protect the citizen in his right to work and his right to live" no less than "in his right to vote," he sketched a prospect of social citizenship that began with the "right to life" and the "right to make a comfortable living" owed to every man. ${ }^{83}$ In agency after agency, in provision for work and relief and bolstering of the nation's families and individuals during the crisis of the Great Depression, the figure of the principal citizen, addressed as wage earner and provider, was male. The welfare of working men was at the heart of New Deal social provision, as the unemployment crisis seemed to dictate. Women were included in New Deal programs, but as individuals and potential wage earners they received only a tiny fraction of what men did. The majority of New Deal-instigated benefits went to

\$1 Jennifer K. Brown, "The Nineteenth Amendment and Women's Equality," Yale Law Journal 102 (June 1993): 2175-2204; on women's jury service, see also Lemons, Woman Citizen, 69-73; Kerber, "Constitutional Right," 29-32; and No Constitutional Right, chap. 4; Cutler, "When Women Became Peers"; Hoff, Law, Gender and Injustice, 224-27. By 1938, twenty-six states and the District of Columbia allowed women to serve on juries, but only eleven did so on equal terms with men (Cutler, 52). Military service for women was not on the political agenda at this time, a period of extremely high antiwar and neutrality sentiment in the United States. On African-American disfranchisement, there is a large literature: for two different approaches, see J. Morgan Kousser, The Shaping of Southern Politics: Suffrage Restriction and the Establishment of the One-Party South, 1880-1910 (New Haven, Conn., 1974); and Glenda Elizabeth Gilmore, Gender and Jim Crow: Women and the Politics of White Supremacy in North Carolina, 1896-1920 (Chapel Hill, N.C., 1996). Nancy A. Hewitt, "From Seneca Falls to Suffrage: Recasting the History of American Women's Activism, 1848-1965" (unpublished paper in my possession) is helpful in opening the question of limitations on other women of color; compare Joan M. Jensen, "Disfranchisement Is a Disgrace": Women and Politics in New Mexico," New Mexico Historical Review 56 (January 1981): 5-35, for evidence of Hispanic women's political participation after 1920 .

${ }^{82}$ See Susan Ware, Beyond Suffrage: Women in the New Deal (Cambridge, Mass., 1981); Pictorial Review clippings in Box 3, folder "NRA 1934-38," Lena Madesin Phillips Collection, Schlesinger Library.

${ }^{83}$ In Citizenship and Social Class, Marshall theorized the expansion of citizenship rights toward the social and economic; compare Fraser and Gordon, "Civil Citizenship against Social Citizenship?" For a recent treatment of the New Deal's reconceptualization of citizenship, see William E. Forbath, "Race, Class and Equal Citizenship," paper delivered at the OAH annual convention, April 17-20, 1997, San Francisco (quoting Roosevelt on 76, 80). Holly Allen, "Fallen Women and Forgotten Men: Gendered Concepts of Community, Home, and Nation, 1932-1945" (PhD dissertation, Yale University, 1996), analyzes the "masculinist" orientation of the New Deal. 
(white) men who were actual or potential husbands, or fathers and providers for families, and went to women, if at all, as wives or widows. As Alice Kessler-Harris has shown, revisions of the Social Security Act in 1939 reinforced rather than refigured women's place as wives and mothers rather than as workers or as equal holders of political rights. And it cannot be said that alternative approaches were absent from the horizon. ${ }^{84}$

As the social and economic aspects of citizenship entitlements took center stage, women's characterization as lesser citizens still held. No longer would marriage to a foreigner break an American woman's bonds of belonging to the nation, but marital position still compromised her capacity to inhabit citizenship fully. In new ways that mattered a great deal-for women and for men-marriage still underlay the garb of civic status, countering the formal political equality of women and preserving a traditional understanding of full citizenship, including its economic substructure. Women as a sex had the formal qualifications for participatory citizenship yet did not graduate to it in political discourse or practice. The uneven and unfinished path to women's full citizenship illustrates the familiar lesson that formal inclusion in the political arena is never as decisive and determinative as formal exclusion. It is worth repeating this lesson, especially if the reiteration points to the power of a persistent mediating structure such as marriage, which operates in gender or racial formation by completing a circuitry that connects private and public life, and links personal choices to state policies. ${ }^{85}$ With expectations of

84 The contrast between the Workers' Bill for social insurance sponsored by Farmer-Labor representative Ernest Lundeen, which had viable support (especially from many sectors of the labor movement) but languished in Congress in the mid-1930s, and the omnibus Social Security Act that was passed is instructive. The Lundeen bill proposed a federal system of insurance for loss of wages through sickness, accident, old age, or maternity for all categories of workers, without discrimination by race, sex, age, national origin, or politics. The Social Security Act distinguished among types of workers in ways supposedly race and sex-neutral yet in fact (for instance, in excluding domestic and farm labor and seasonal or part-time work) having a discriminatory impact on the basis of race and sex; and its double categorization of social insurance (for able-bodied workers) and public assistance (for those disabled or dependent) created a two-track system aligned with gender. See Kenneth Casebcer, "The Workers" Unemployment Insurance Bill: American Social Wage, Labor Organization, and Legal Ideology," in Labor Law in America: Historical and Critical Essays, Christopher L. Tomlins and Andrew J. King, eds. (Baltimore, Md., 1992), 231-60 (my thanks to David Montgomery for pointing nut this essay). On Social Security and its origins, see Kessler-Harris, "Designing Women and Old Fools"; Barbara Nelson, "The Gender, Race and Class Origins of Early Welfare Policy and the Welfare state," in Tilly and Gurin, Women, Politics and Change, 413-35: Linda Gordon, Pitied But Not Entitled. Single Mothers and the History of Welfare, 1890-1935 (New York, 1994); Gwendolyn Mink, The Wages of Motherhood: Inequality in the Welfare State, 19/7-1942 (Ithaca, N.Y.. 1995). The last two are especially enlightening on the central part of women reformers in designing the gender-differentiated outcome.

Married women workers suffered economic discrimination of the most dirct sort during the Depression, especially in public employment. The notion was frequently voiced that employed married women's departure from their jobs would solve the unemployment crisis. Lois Scharf has persuasively argued that this pressure did not take married women out of the labor market but moved them lower down in it. (The proportion of married women at work increased from 12 to 17 percent during the 1930s.) See Ruth Milkman, "Women's Work and the Economic Crisis: Some Lessuns from the Great Depression," Review of Racical Political Economics 8 (Spring 1976): 73-97; Lois Scharf, To Work and to Wed: Female Employment, Feminism, and the Great Depression (Westport, Conn., 1980); Alice Kessler-Harris, Out to Work: A History of Wage-Earning Women in the United States (New York, 1982), 250-72; Becker, Origins of the Equal Rights Amendmemt, 133-51.

*s I have adopted Mariana Valverde's phrase "gender formation," which she prefers to "gender structure" for its more dynamic sense in her comment in "Dialogue: Gender History/Women's History; Is Feminist Scholarship Losing Its Critical Edge?"Journal of Women s History 5 (Spring 1993): 123; and compare Omi and Winant. Racial Formation. 
"social" citizenship expanding in the twentieth century, the federal government reached ever more noticeably into individuals' lives, incorporating expectations about husbands and wives. The stakes and consequences of this marital orientation of policy are difficult to measure, not because they are small but because they are profound, beneath the surface. Just as married women's deprivation of citizenship had been experienced for the most part one by one, individually, so was the orientation of social policy absorbed as the result of personal choices based on decisions to marry, more than as the determination of the public order.

Nancy F. Cott is Stanley Woodward Professor of History and American Studies at Yale University, where she has taught since 1975 . Her publications include The Bonds of Womanhood: "Woman's Sphere" in New England, 1780-1835 (1977), The Grounding of Modern Feminism (1987), and (editor) A Woman Making History: Mary Ritter Beard through Her Letters (1991). This article is an offshoot of a book Cott is completing on the history of marriage as a civic institution, considered essential to the purposes of the nation by public authorities in the United States and supported by their political thinking and legislative and judicial practices. 